\title{
Inhibitors of Cyclin-Dependent Kinases: Types and Their Mechanism of Action
}

\author{
Paweł Łukasik ${ }^{1}$, Irena Baranowska-Bosiacka ${ }^{2}$, Katarzyna Kulczycka ${ }^{3}$ and Izabela Gutowska ${ }^{1, *(D)}$ \\ 1 Department of Medical Chemistry, Pomeranian Medical University in Szczecin, Powstancow Wlkp. 72 Av., \\ 70-111 Szczecin, Poland; pawel_lukasik@yahoo.co.uk \\ 2 Department of Biochemistry, Pomeranian Medical University in Szczecin, Powstancow Wlkp. 72 Av., \\ 70-111 Szczecin, Poland; ika@pum.edu.pl \\ 3 Department of Pharmaceutical Chemistry, Pomeranian Medical University in Szczecin, \\ Powstancow Wlkp. 72 Av., 70-111 Szczecin, Poland; katarzyna.kulczycka@pum.edu.pl \\ * Correspondence: izagut@poczta.onet.pl
}

check for updates

Citation: Łukasik, P.;

Baranowska-Bosiacka, I.; Kulczycka,

K.; Gutowska, I. Inhibitors of

Cyclin-Dependent Kinases: Types and Their Mechanism of Action. Int. J. Mol. Sci. 2021, 22, 2806. https:// doi.org/10.3390/ijms22062806

Academic Editor: Antonio Giordano

Received: 12 February 2021

Accepted: 5 March 2021

Published: 10 March 2021

Publisher's Note: MDPI stays neutral with regard to jurisdictional claims in published maps and institutional affiliations.

Copyright: (C) 2021 by the authors Licensee MDPI, Basel, Switzerland. This article is an open access article distributed under the terms and conditions of the Creative Commons Attribution (CC BY) license (https:/ / creativecommons.org/licenses/by/ $4.0 /)$.

\begin{abstract}
Recent studies on cyclin-dependent kinase (CDK) inhibitors have revealed that small molecule drugs have become very attractive for the treatment of cancer and neurodegenerative disorders. Most CDK inhibitors have been developed to target the ATP binding pocket. However, CDK kinases possess a very similar catalytic domain and three-dimensional structure. These features make it difficult to achieve required selectivity. Therefore, inhibitors which bind outside the ATP binding site present a great interest in the biomedical field, both from the fundamental point of view and for the wide range of their potential applications. This review tries to explain whether the ATP competitive inhibitors are still an option for future research, and highlights alternative approaches to discover more selective and potent small molecule inhibitors.
\end{abstract}

Keywords: cyclin-dependent kinase inhibitors; cancer; cell cycle; CDKs; CDK inhibitors

\section{Cyclin-Dependent Kinases (CDKs)}

Protein phosphorylation is a necessary mechanism to drive numerous cellular processes such as cell division, migration, differentiation and programmed cell death. This process is regulated by many enzymes, including cyclin-dependent kinases (CDKs) which phosphorylate proteins on their serine and threonine amino acid residues. The 20 members of CDK family known to this day regulate the cell cycle, transcription and splicing [1]. A number of kinase inhibitors are emerging every day as potential small molecule drugs, with some of them already being approved by the United States Food and Drug Administration (FDA). Moreover, these already approved kinase targeting drugs now account for more than a quarter of all available drugs [2]. In relation to CDK inhibitors, drugs such as Palbociclib 1, Ribociclib 2 and Abemaciclib 3, have been approved for ER+/HER2advanced breast cancer treatment [3]. Until recently, the focus of the research was aimed at the highly conserved ATP binding sites of each CDK kinase. Hence, the development of CDK inhibitors has been extremely challenging due to the difficulty of obtaining sufficient selectivity with typical ATP-mimetic compounds. The greatest number of reported compounds has been identified to target the ATP binding pocket. Most recent studies suggest that inhibitors targeting hydrophobic pockets outside the ATP binding site may provide an opportunity for rational target selectivity [4]. Figure 1 illustrates the typical protein structure of the CDK enzyme. The diagram depicts the structural features of a typical kinase domain. Specifically highlighted are the binding pockets of different types of inhibitors, as well as the activation loop. 


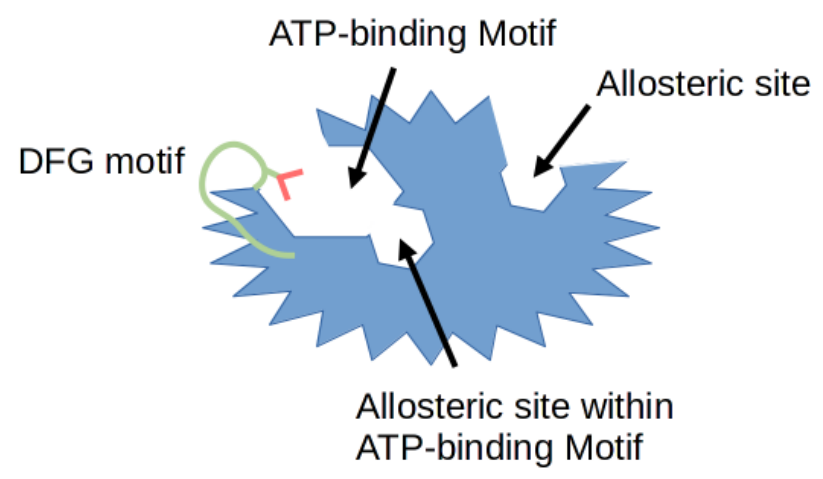

Figure 1. Schematic representation of different types of binding pockets. The protein kinase is shown in blue, with the Asp-Phe-Gly (DFG) motif in green. Red color denotes the aspartate amino acid residue of the DFG motif. The particular regions where different types of inhibitors bind are described below, the allosteric pocket is only a visualization and its place can be anywhere outside the ATP binding site.

\section{Cyclin-Dependent Kinase (CDK) Inhibitors in Drug Development}

CDK family is known to regulating the cell cycle, transcription and splicing. Deregulation of any of the stages of the cell cycle or transcription leads to apoptosis but, if uncorrected, it can result in a series of diseases such as cancer or neurodegenerative diseases [1,5-7].

Within the last 20 years important advances have been achieved in the development of effective strategies to inhibit CDK kinases. Access of the substrate to the active site of CDK kinase is regulated by the activation loop (A-loop) which is very flexible. The A-loop contains between 20-30 amino acids marked by the conserved Asp-Phe-Gly (DFG) tripeptide motif at the proximal end. Phosphorylation of the activation loop activates the kinase. In this state, the DFG sequence fits snugly into a hydrophobic back pocket adjacent to the ATP binding site. Conversely, in the inactive state the DFG motif swings outwards by partially blocking both the ATP and substrate binding pockets [8].

To date, six types of small molecule kinase inhibitors have been defined by the pharmaceutical industry based on their biochemical mechanisms of action (Figure 2). Type I inhibitors interact directly with the ATP binding site and react with the active form of the kinase which is in the DFG-in state and with a phosphorylated activation loop (activation segment). These inhibitors mimic the hydrogen bonds created between the adenine ring of the ATP and the hinge region of the enzyme. Type II inhibitors interact with a DFG-out catalytically inactive conformation of the enzyme and, like type I inhibitors, explore the hinge region and the adenine binding pocket. Type III inhibitors are non-competitive with ATP as they bind to the hydrophobic pocket next to the ATP-binding site, while type IV inhibitors bind away from the ATP binding pocket. Both, type III and IV inhibitors are allosteric in nature [8]. Type $\mathrm{V}$ inhibitors interact with two separate regions of the protein kinase domain. This group of inhibitors has been classified as bi-substrate inhibitors. These five classes of inhibitors interact reversibly, while type VI inhibitors form a covalent bond with their target kinase (Figure 2) [9]. 


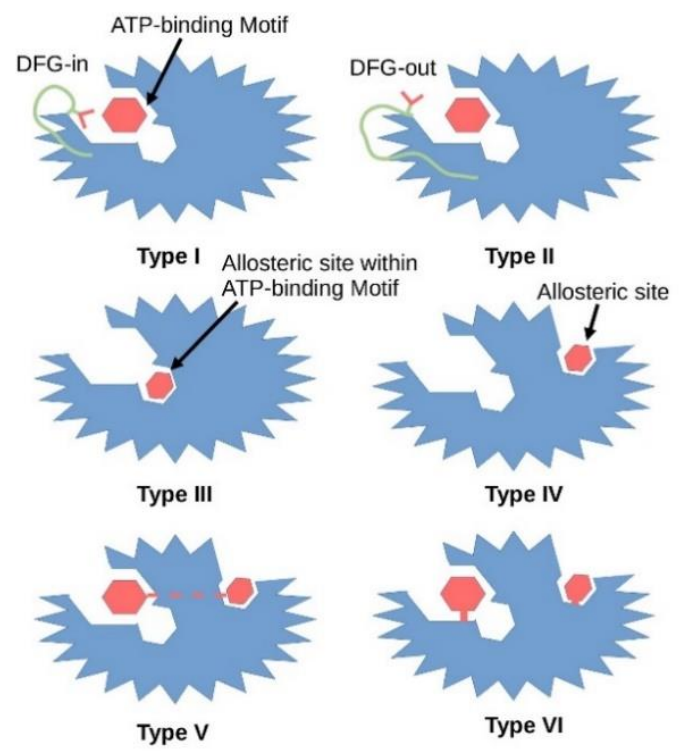

Figure 2. Graphical illustration of different types of kinase inhibitors and their mode of action. Dark red hexagon represents an inhibitor. The protein kinase is shown in blue, the DFG motif in green, the aspartate amino acid residue of the DFG motif in red. In $2015 \mathrm{Wu}$ demonstrated that co-crystal structure of 3-phosphoinositide-dependent protein kinase 1 (PDPK1, PDK1) with ATP showed that type I inhibitors interact with the active conformation of the enzyme where the aspartate residue of the DFG motif points into the ATP binding pocket, while type II inhibitors stabilize the inactive conformation of the enzyme where the aspartate residue faces outward of the binding site (PDB entry: 4RRV). Type III inhibitors interact with the allosteric site within the ATP binding pocket. Type IV inhibitors interact with the allosteric site. However, the allosteric pocket is only a visualization and its place can be anywhere outside the ATP binding site. Type V inhibitors interact with both the allosteric and ATP binding pockets. Type VI inhibitors form covalent bonds with either the ATP binding pocket or the allosteric pocket.

\section{Type I Inhibitors}

Many heterocyclic compounds can mimic the hydrogen binding motif of adenine, therefore many type I inhibitors have been discovered. As mentioned above, these compounds interact with the ATP-site of the kinase in its active (DFG-in) conformation and with phosphorylated polypeptide region (activation segment) which lies outside the active site pocket. First generation of structurally diverse ATP competitive small molecule type I CDK inhibitors, produced in the late 1990s and early 2000s, have entered clinical trials to treat numerous solid tumors and hematopoietic malignances. Among the list of compounds that have been synthesized as CDK inhibitors, Flavopiridol (Alvocidib) 4 (Figure 3), a flavonoid derived from an indigenous plant from India, is active against CDK1, CDK2, CDK4, CDK6, and $\mathrm{CDK} 9$ with $\mathrm{IC}_{50}$ values in the $20-100 \mathrm{nM}$ range (Table 1) [10-13]. Flavopiridol can inhibit cell cycle progression in G1 as well as G2 phase due to inhibition of CDK2/4 and CDK1 activity, respectively. Early clinical trials proved ineffective because of unsatisfactory efficacy and high toxicity $[14,15]$. However, later studies confirmed its clinical efficacy in hematological malignancies, and it was granted orphan drug designation for the treatment of patients with acute myeloid leukemia (Table 2) [16]. 
<smiles>CN1CC[C@H](c2c(O)cc(O)c3c(=O)cc(-c4ccccc4Cl)oc23)[C@H](O)C1</smiles>

Flavopiridol 4<smiles>CCC(CO)Cc1nc(NCc2ccccc2)c2ncn(C(C)C)c2n1</smiles><smiles>O=C1N=C(NCc2cccs2)S/C1=C\c1ccc2ncccc2c1</smiles><smiles>CCc1cnn2c(NCc3ccc[n+]([O-])c3)cc(N3CCCCC3CCO)nc12</smiles>

Dinaciclib 6<smiles>CNC(=O)c1nn(C)c2c1C(C)(C)Cc1cnc(Nc3ccc(N(C)C)cc3)nc1-2</smiles>

Milciclib 7<smiles>CC(=O)c1c(C)c2cnc(Nc3ccc(N4CCNCC4)cn3)nc2n(C2CCCC2)c1=O</smiles>

Palbociclib 1<smiles>CN(C)C(=O)c1cc2cnc(Nc3ccc(N4CCNCC4)cn3)nc2n1C1CCCC1</smiles>

Ribociclib 2<smiles>CCN1CCN(Cc2ccc(Nc3ncc(F)c(-c4cc(F)c5nc(C)n(C(C)C)c5c4)n3)nc2)CC1</smiles><smiles>OC[C@H]1O[C@@H](n2cnc3cc(Cl)c(Cl)cc32)[C@H](O)[C@@H]1O</smiles>

DRB 19<smiles>COc1ccnc2[nH]cc(-c3ccnc(N)n3)c12</smiles>

Meriolin 312<smiles></smiles>

Variolin B 10<smiles>Nc1nccc(-c2c[nH]c3c(Br)ccc(O)c23)n1</smiles>

Meridianin E 11<smiles></smiles>

Nortopsentins A-C 13<smiles>Cc1ncc(-c2ccnc(Nc3ccc(S(C)(=O)=O)cc3)n2)n1C(C)C</smiles>

AZD5438 15

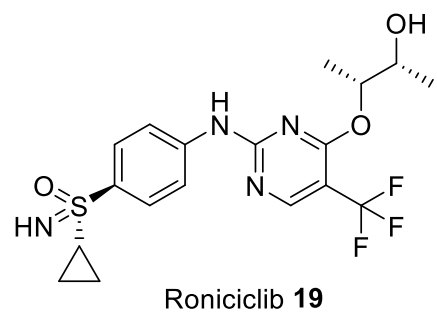

Roniciclib 19<smiles>CC(C)(C)c1cnc(CSc2cnc(NC(=O)C3CCNCC3)s2)o1</smiles>

SNS-032 16

Figure 3. Chemical structures of some of the most studied type I cyclin-dependent kinase (CDK) inhibitors.

Roscovitine (Seliciclib) 5 (Figure 3), one of the best known CDK inhibitors, is active against CDK2, CDK5, CDK7 and CDK9 (Table 1). This compound is, by far, the most effective inhibitor of $\mathrm{CDK} 5 / \mathrm{p} 25\left(\mathrm{IC}_{50}=160 \mathrm{nM}\right.$ [17]), as shown by numerous studies using this compound as a potential drug against cancer, neurodegenerative or viral diseases, inflammation, polycystic kidney disease (PKD) and glomerulonephritis (Table 2) [18-22]. However, despite many successful preclinical studies, results from several clinical trials are not that promising [23].

Another compound is Dinaciclib 6 (Figure 3), which proved to be a very effective small molecule inhibitor against $\mathrm{CDK} 5\left(\mathrm{IC}_{50}=1 \mathrm{nM}\right.$ [24]) (Table 1). Preclinical studies have 
shown that Dinaciclib is effective against solid tumors and chronic lymphocytic leukemia (CLL), without adversely affecting T-lymphocytes and their numbers (Table 2) [25].

Moreover, Milciclib 7 (Figure 3), an orally bioavailable inhibitor of cyclin-dependent kinases (CDKs) and several other protein kinases responsible for controlling cell growth and replication, has recently obtained the orphan drug designation for thymic carcinoma. It is currently under investigation as a potential drug target for treatment of glioma and hepatocellular carcinoma (HCC) (Table 2) [26,27]. It inhibits CDK2 with $\mathrm{IC}_{50}$ of $45 \mathrm{nM}$ and exhibits submicromolar activity against other CDKs including CDK1, CDK4 and CDK5 resulting in a block in the G1 (gap) phase of the cell cycle (Table 1) [28]. Furthermore, Milciclib was found to reduce levels of microRNAs, miR-221 and miR-222, which promote the formation of blood supply (angiogenesis) in cancer tumors [29].

And finally, Palbociclib 1 and Ribociclib 2 (Figure 3), novel CDK4/6 inhibitors, were approved as effective drugs against HR+/HER2- metastatic breast cancer (Table 2) [30,31]. They selectively inhibit CDK4/6 (Table 1), thereby inhibiting retinoblastoma ( $\mathrm{Rb}$ ) protein phosphorylation early in the G1 phase leading to cell cycle arrest, causing defects in DNA replication and efficiently suppress cancer cell proliferation. Most recent data show that both drugs demonstrate a synergistic effect when combined with other drugs, for example Palbociclib and aromatase inhibitor Letrozole [32], Ribociclib and either anaplastic lymphoma kinase (ALK) inhibitor or the mitogen-activated protein kinase kinase (MAP2K, MEK) inhibitor Trametinib [33]. Moreover, utilizing this approach leads to a significant reduction in the development of resistance during prolonged treatment courses [31].

In addition, Tamoxifen 8 has been found to be effective against breast cancer. It reduces CDK5 activity by interacting with $\mathrm{p} 25$ and $\mathrm{p} 35$, thus preventing CDK5 activation. Tamoxifen can also lower Tau protein phosphorylation, which may suggest that tamoxifen could be used against Alzheimer's disease [34].

Yet another inhibitor, 5,6-dichlorobenzimidazone-1- $\beta$-D-ribofuranoside (DRB) 9 (Figure 3) possesses high selectivity against CDK9, with nearly 25-fold difference in potency over CDK2 and CDK7 (Table 1) [35]. In HeLa cells, DRB (75 $\mu \mathrm{M})$ inhibited 60-75\% of nuclear heterogeneous RNA (hnRNA) synthesis. DRB inhibited a HeLa protein kinase which phosphorylated an RNA polymerase II-derived peptide [36]. DRB can also inhibit HIV transcription $\left(\mathrm{IC}_{50}=\sim 4 \mu \mathrm{M}\right)$ by targeting elongation enhanced by the HIV-encoded transactivator Tat (Table 2) [37].

Table 1. Kinase inhibitory activities of type I CDK inhibitors.

\begin{tabular}{|c|c|c|c|c|c|c|c|c|c|}
\hline \multirow{2}{*}{ Inhibitor } & \multicolumn{9}{|c|}{ Kinase $\mathrm{IC}_{50}[\mathrm{nM}]$} \\
\hline & CDK1/B & CDK2/A & CDK2/E & CDK4/D & CDK5/p25 & CDK6/D & CDK7/H & CDK8/C & CDK9/T1 \\
\hline $\begin{array}{c}\text { Flavopiridol } \\
\mathbf{4}[38,39]\end{array}$ & 30 & 100 & 100 & $20-40$ & - & 60 & 110 & - & 20 \\
\hline $\begin{array}{c}\text { Roscovitine } \\
5[40]\end{array}$ & 650 & 700 & 700 & $>100,000$ & 160 & $>100,000$ & 460 & $>100,000$ & 600 \\
\hline $\begin{array}{c}\text { RO-3306 } 17 \\
{[41]}\end{array}$ & 35 & - & 340 & $>2000$ & - & - & - & - & - \\
\hline $\begin{array}{c}\text { Dinaciclib } 6 \\
\text { [42] }\end{array}$ & 3 & 1 & 1 & 100 & 1 & - & - & - & 4 \\
\hline $\begin{array}{c}\text { Milciclib } 7 \\
\text { [28] }\end{array}$ & 398 & 45 & 363 & 160 & 265 & - & 150 & - & - \\
\hline $\begin{array}{l}\text { Palbociclib } \\
\mathbf{1}[43]\end{array}$ & $>10,000$ & $>10,000$ & $>10,000$ & 11 & $>10,000$ & 15 & - & - & - \\
\hline $\begin{array}{c}\text { Ribociclib } 2 \\
\text { [44] }\end{array}$ & 113,000 & 76,000 & 76,000 & 10 & 43,900 & 39 & - & - & - \\
\hline $\begin{array}{c}\text { Abemaciclib } \\
3 \text { [45] }\end{array}$ & 1627 & - & 504 & 2 & 355 & 10 & 3910 & - & 57 \\
\hline $\begin{array}{c}\text { BS-181 } 18 \\
{[46]}\end{array}$ & 8100 & 730 & 880 & 33,000 & 3000 & 47,000 & 21 & - & 4200 \\
\hline DRB 9 [47] & 17,000 & - & $>10,000$ & $>10,000$ & - & - & $>10,000$ & $>10,000$ & 340 \\
\hline
\end{tabular}


Table 1. Cont.

\begin{tabular}{|c|c|c|c|c|c|c|c|c|c|}
\hline \multirow{2}{*}{ Inhibitor } & \multicolumn{9}{|c|}{ Kinase $\mathrm{IC}_{50}[\mathrm{nM}]$} \\
\hline & CDK1/B & CDK2/A & CDK2/E & CDK4/D & CDK5/p25 & CDK6/D & CDK7/H & CDK8/C & CDK9/T1 \\
\hline $\begin{array}{l}\text { Meriolin } 3 \\
\mathbf{1 2}[48]\end{array}$ & 170 & 11 & - & $>100,000$ & 170 & $>100,000$ & $>100,000$ & - & 6 \\
\hline $\begin{array}{c}\text { Variolin B } \\
\mathbf{1 0} \text { [49] }\end{array}$ & 60 & 80 & - & $>10,000$ & 90 & $>10,000$ & $>1000$ & - & 26 \\
\hline $\begin{array}{c}\text { Meridianin } \\
\text { E 11 [50] }\end{array}$ & 180 & 800 & 1800 & 3000 & 150 & - & - & - & 18 \\
\hline $\begin{array}{l}\text { Nortopsentins } \\
\quad 13[51]\end{array}$ & $310-900$ & - & - & - & - & - & - & - & - \\
\hline $\begin{array}{c}\text { AZD } 5438 \\
\mathbf{1 5}[52]\end{array}$ & 16 & 45 & 6 & 449 & 14 & 21 & 821 & - & 20 \\
\hline $\begin{array}{c}\text { Roniciclib } \\
19 \text { [53] }\end{array}$ & 7 & - & 9 & 11 & - & - & 25 & - & 5 \\
\hline $\begin{array}{c}\text { SNS-032 } 16 \\
{[54]}\end{array}$ & 480 & 38 & 48 & 925 & $\begin{array}{c}340 \\
\text { (CDK5/p35) }\end{array}$ & - & 62 & - & 4 \\
\hline
\end{tabular}

Table 2. Type I CDK inhibitors at different phases of clinical and pre-clinical studies. Trial information obtained from ClinicalTrials.gov as of January 2021.

\begin{tabular}{|c|c|c|c|c|c|}
\hline Inhibitor & Main Targets & $\begin{array}{l}\text { Condition or } \\
\text { Disease }\end{array}$ & Phase & Status & Identifier \\
\hline Flavopiridol 4 & $\begin{array}{c}\text { CDK1, CDK2, } \\
\text { CDK4, CDK6, } \\
\text { CDK9 }\end{array}$ & $\begin{array}{c}\text { Acute Myeloid } \\
\text { Leukemia (AML) }\end{array}$ & on the market & "orphan drug" & - \\
\hline \multirow{4}{*}{ Roscovitine 5} & \multirow{4}{*}{$\begin{array}{c}\text { CDK2, CDK7, } \\
\text { CDK9 }\end{array}$} & $\begin{array}{c}\text { Pituitary Cushing } \\
\text { Disease }\end{array}$ & II & active & $\begin{array}{l}\text { NCT02160730 } \\
\text { NCT03774446 }\end{array}$ \\
\hline & & Cystic Fibrosis & II & terminated & NCT02649751 \\
\hline & & $\begin{array}{c}\text { Advanced Solid } \\
\text { Tumors }\end{array}$ & I & terminated & NCT00999401 \\
\hline & & Lung Cancer & II & terminated & NCT00372073 \\
\hline RO-3306 17 [41] & CDK1 & $\begin{array}{c}\text { Acute Myeloid } \\
\text { Leukemia (AML) }\end{array}$ & pre-clinical & - & - \\
\hline \multirow[t]{2}{*}{ Dinaciclib 6} & \multirow{2}{*}{$\begin{array}{l}\text { CDK1, CDK2, } \\
\text { CDK5, CDK9 }\end{array}$} & $\begin{array}{c}\text { Chronic } \\
\text { Lymphocytic } \\
\text { Leukemia (CLL) }\end{array}$ & on the market & "orphan drug" & - \\
\hline & & $\begin{array}{l}\text { Breast and Lung } \\
\text { Cancers }\end{array}$ & II & terminated & NCT00732810 \\
\hline \multirow{2}{*}{ Milciclib 7} & \multirow{2}{*}{$\begin{array}{l}\text { CDK1, CDK2, } \\
\text { CDK4, CDK7 }\end{array}$} & $\begin{array}{c}\text { Hepatocellular } \\
\text { Carcinoma (HCC) }\end{array}$ & II & active & NCT03109886 \\
\hline & & Thymic Carcinoma & II & terminated & $\begin{array}{l}\text { NCT01301391 } \\
\text { NCT01011439 }\end{array}$ \\
\hline \multirow{3}{*}{ Palbociclib 1} & \multirow{3}{*}{ CDK4, CDK6 } & \multirow{2}{*}{$\begin{array}{l}\mathrm{HR}+/ \text { HER2- } \\
\text { Breast Cancer }\end{array}$} & on the market & $\begin{array}{c}\text { used in } \\
\text { combination with } \\
\text { Letrozole }\end{array}$ & - \\
\hline & & & III & $\begin{array}{l}\text { active, to be used } \\
\text { with other drugs } \\
\text { like Fulvestrant }\end{array}$ & NCT02692755 \\
\hline & & $\begin{array}{l}\text { Head and Neck, } \\
\text { Brain, Colon, and } \\
\text { other Solid } \\
\text { Cancers }\end{array}$ & II & $\begin{array}{l}\text { active, to be used } \\
\text { alone and in } \\
\text { combination with } \\
\text { different drugs }\end{array}$ & $\begin{array}{l}\text { NCT02255461 } \\
\text { NCT03446157 } \\
\text { NCT02896335 } \\
\text { NCT03965845 }\end{array}$ \\
\hline
\end{tabular}


Table 2. Cont.

\begin{tabular}{|c|c|c|c|c|c|}
\hline Inhibitor & Main Targets & $\begin{array}{l}\text { Condition or } \\
\text { Disease }\end{array}$ & Phase & Status & Identifier \\
\hline \multirow{3}{*}{ Ribociclib 2} & \multirow{3}{*}{ CDK4, CDK6 } & \multirow{2}{*}{$\begin{array}{l}\mathrm{HR}+/ \text { HER2- } \\
\text { Breast Cancer }\end{array}$} & on the market & $\begin{array}{l}\text { used in } \\
\text { combination with } \\
\text { Letrozole }\end{array}$ & - \\
\hline & & & III & $\begin{array}{l}\text { active, to be used } \\
\text { with other drugs } \\
\text { like Fulvestrant }\end{array}$ & $\begin{array}{l}\text { NCT02422615 } \\
\text { NCT03439046 } \\
\text { NCT03294694 }\end{array}$ \\
\hline & & $\begin{array}{l}\text { Prostate, and other } \\
\text { Solid Cancers }\end{array}$ & II & $\begin{array}{l}\text { active, to be used } \\
\text { alone and in } \\
\text { combination with } \\
\text { different drugs }\end{array}$ & $\begin{array}{l}\text { NCT02555189 } \\
\text { NCT01543698 } \\
\text { NCT02934568 }\end{array}$ \\
\hline \multirow{3}{*}{ Abemaciclib 3} & \multirow{3}{*}{ CDK4, CDK6 } & \multirow{2}{*}{$\begin{array}{l}\text { HR+/HER2- } \\
\text { Breast Cancer }\end{array}$} & on the market & $\begin{array}{c}\text { used in } \\
\text { combination with } \\
\text { Fulvestrant }\end{array}$ & - \\
\hline & & & III & $\begin{array}{l}\text { active, to be used } \\
\text { with other drugs } \\
\text { like Letrozole }\end{array}$ & NCT02763566 \\
\hline & & $\begin{array}{l}\text { Lung, Brain, Colon, } \\
\text { and other Solid } \\
\text { Cancers }\end{array}$ & II or III & $\begin{array}{l}\text { active, to be used } \\
\text { alone and in } \\
\text { combination with } \\
\text { different drugs }\end{array}$ & $\begin{array}{l}\text { NCT04545710 } \\
\text { NCT02152631 } \\
\text { NCT03220646 } \\
\text { NCT04616183 } \\
\text { NCT03310879 }\end{array}$ \\
\hline BS-181 18 [46] & CDK7 & $\begin{array}{l}\text { Breast, Lung, } \\
\text { Prostate and } \\
\text { Colorectal Cancers }\end{array}$ & pre-clinical & - & - \\
\hline DRB 9 [55] & $\begin{array}{c}\text { CDK7, CDK8, } \\
\text { CDK9 }\end{array}$ & HIV Transcription & pre-clinical & - & - \\
\hline Meriolin 312 [48] & $\begin{array}{l}\text { CDK1, CDK2, } \\
\text { CDK5, CDK9 }\end{array}$ & $\begin{array}{c}\text { Neuroblastoma, } \\
\text { Glioma, Myeloma, } \\
\text { Colon Cancer }\end{array}$ & pre-clinical & - & - \\
\hline Variolin B 10 [56] & $\begin{array}{l}\text { CDK1, CDK2, } \\
\text { CDK5, CDK9 }\end{array}$ & Murine Leukemia & pre-clinical & - & - \\
\hline $\begin{array}{l}\text { Meridianin E } 11 \\
\text { [57] }\end{array}$ & $\begin{array}{l}\text { CDK1, CDK5, } \\
\text { CDK9 }\end{array}$ & $\begin{array}{l}\text { Larynx Carcinoma, } \\
\text { Myeloid Leukemia }\end{array}$ & pre-clinical & - & - \\
\hline $\begin{array}{c}\text { Nortopsentins } \mathbf{1 3} \\
{[58]}\end{array}$ & CDK1 & $\begin{array}{l}\text { Malignant Pleural } \\
\text { Mesothelioma } \\
\text { (MPM) }\end{array}$ & pre-clinical & - & - \\
\hline AZD5438 15 & $\begin{array}{l}\text { CDK1, CDK2, } \\
\text { CDK5, CDK6, } \\
\text { CDK9 }\end{array}$ & $\begin{array}{l}\text { Advanced Solid } \\
\text { Malignancies }\end{array}$ & I & terminated & NCT00088790 \\
\hline Roniciclib 19 & $\begin{array}{l}\text { CDK1, CDK2, } \\
\text { CDK4, CDK7, } \\
\text { CDK9 }\end{array}$ & $\begin{array}{c}\text { Lung and } \\
\text { Advanced Solid } \\
\text { Cancers }\end{array}$ & II & terminated & $\begin{array}{l}\text { NCT02161419 } \\
\text { NCT01573338 } \\
\text { NCT02656849 }\end{array}$ \\
\hline SNS-032 16 & $\begin{array}{l}\text { CDK2, CDK7, } \\
\text { CDK9 }\end{array}$ & $\begin{array}{l}\text { Chronic } \\
\text { Lymphocytic } \\
\text { Leukemia and } \\
\text { other Solid } \\
\text { Cancers }\end{array}$ & I & terminated & $\begin{array}{l}\text { NCT00446342 } \\
\text { NCT00292864 }\end{array}$ \\
\hline
\end{tabular}

Novel alkaloids, acting as CDK inhibitors, were also found in some marine organisms. Variolins, 7-azaindole based alkaloids isolated from the antarctic sponge Kirkpatrickia variolosa $[59,60]$, showed in vitro activity against a murine (P388) leukemia cell 
line with submicromolar potencies by preventing cell proliferation, and inducing apoptosis (Table 2) [56,59]. Variolin B 10 (Figure 3), in particular, was found to inhibit CDK1 and CDK2 kinases, in the micromolar concentration range (Table 1) [61]. Meridianins A-G, a family of 3-(2-aminopyrimidine)indoles, which originate from the ascidian Aplidium meridianum, were demonstrated to inhibit several protein kinases, especially Meridianin E 11 (Figure 3), which can selectively inhibit CDK1 and CDK5 in the low micromolar range (Table 1) [62]. Based on the latter two compounds, Meriolins 12, a new class of inhibitors, have been designed. These new derivatives have been reported to strongly inhibit various protein kinases, especially CDK1, CDK2, CDK4 and CDK9 (Table 1) [48]. Most recent analysis provides a high potential of Meriolins in the treatment of cancer and noncancer pathologies such as polycystic kidney disease, neurodegenerative diseases, stroke, chronic inflammation, and bipolar disorders (Table 2) [48]. Nortopsentins A-C 13 (Figure 3), antifungal 1,4-bisindolylimidazole marine alkaloids, having an imidazole as a spacer between the two indole units, isolated from the Caribbean deep sea Spongosorites ruetzleri, displayed in vitro cytotoxicity against P388 leukemia cells ( $\left.\mathrm{IC}_{50} 4.5-20.7 \mu \mathrm{M}\right)$. Analogues in which the imidazole ring of the alkaloid was replaced by other five or six membered heterocycles were able to inhibit the activity of the cyclin-dependent kinase 1 (CDK1) with submicromolar $\mathrm{IC}_{50}$ values (in particular 3-[(2-indolyl)-5-phenyl]-pyridines, phenyl-thiazolyl-7-azaindoles, indolyl-thiazolyl-4-azaindole and indolyl-thiazolyl-7-azaindole derivatives) (Table 1) [51] Preliminary results indicate, that Nortopsentins, and their analogues, were active against malignant pleural mesothelioma (MPM), a very aggressive human malignancy poorly responsive to currently available therapies (Table 2) [58].

Recent development has enabled combinatorial treatment regimens which can demonstrate synergistic anticancer mechanisms. For instance, THZ1 14 (Figure 7) a covalent CDK7 inhibitor, was found to selectively downregulate CDK7-mediated phosphorylation of RNA polymerase II, indicative of transcriptional inhibition. Further investigations revealed that the survival of triple negative breast cancer (TNBC) cells relied heavily on the B-cell lymphoma 2 (BCL-2)/B-cell lymphoma-extra large (BCL-XL) signaling axes in cells. Thus, combining the CDK7 inhibitor THZ1 with the BCL-2/BCL-XL inhibitors (ABT-263/ABT199) offer a preclinical proof to significantly improve the poor prognosis in TNBC [63].

However, the complexity of CDK biology and the undesired toxicity related to the offtarget effects of the existing pan-CDK inhibitors, led to decisions by several pharmaceutical companies to discontinue the development of many potential anti-cancer agents, exampled with AZD5438 15, Roniciclib, SNS-032 16, RO-3306 17, BS-181 18 and Roniciclib 19 (Figure 3) (Tables 1 and 2) [64-66]. Therefore, new classes of more selective CDK inhibitors, with strong potential to deliver a meaningful therapeutic impact, were needed.

One of those compounds is CDK5 inhibitory protein (CIP), a small protein which contribute to nerve cells' degeneration. CIP specifically blocks the hyperactivated state of CDK5 only when it is linked to $25 / \mathrm{p} 29$, while allowing normal activation of CDK5 by p35/p39. The selective inhibition of p25/CDK5 hyperactivation in vivo, through overexpression of CIP, reduced neurodegeneration and improved cognitive function of transgenic mice, without affecting normal neurodevelopment [67]. These findings suggest that CIP could possibly be used to selectively inhibit the p25/CDK5 hyperactivation as a potential therapeutic target to treat certain cancers caused by aberrant CDK5 activation.

\section{Type 1.5 Inhibitors}

Another strategy to generate novel class of inhibitors has been devised by targeting the inactive unphosphorylated monomeric kinase, not the heterodimer complex. In case of CDK2, a series of compounds based on a quinoline scaffold which bind tightly to the ATP binding site and adjacent back pocket behind the gatekeeper have been synthesized. The binding mode with quinoline-based derivative 20 (Figure 4) in CDK2 demonstrates that the DGF motif is in the "in" state, and 20 interacts not only with the ATP binding site but also disrupts the binding of cyclin A by inducing extensive conformational changes in the 
C helix (PDB entry 4NJ3). This type of binding to the DFG-in inactive conformation is also referred to as type 1.5 inhibition [68].<smiles>COC(=O)[C@H](Cc1ccc(O)cc1)NC(=O)c1cc(C(=O)O)c2cc(-c3cccc(Cl)c3)ccc2n1</smiles>

Figure 4. Chemical structure of quinoline-based type 1.5 inhibitor of monomeric CDK2.

Despite showing significant binding affinities none of the compounds exhibited high cellular activity. Quinoline-based 20 bound CDK2 with a $\mathrm{K}_{\mathrm{i}}$ value of $0.14 \mu \mathrm{M}$ determined using the CDK2 fluorescence polarization (FP) binding assay and $\mathrm{K}_{\mathrm{d}}=0.3 \mu \mathrm{M}$ using the temperature-dependent circular dichroism assay (TdCD). Moreover, the $\mathrm{IC}_{50}$ is greater than $10 \mu \mathrm{M}$ in the CDK2/cyclin A enzyme assay. The explanation might stem from the poor permeability resulting from the carboxyl group, as well as the competition of these inhibitors with cyclin A binding to the monomeric CDK2 (Table 3) [68]. These findings clearly demonstrate the potential of these CDK2 inhibitors. Hopefully, by blocking the interaction with cyclin A, these agents will exhibit different cellular effects which can translate into novel therapeutic possibilities.

Table 3. Selected biological data obtained from different assays with quinoline-based compound demonstrating that it targets monomeric CDK2.

\begin{tabular}{cccc}
\hline \multicolumn{4}{c}{ Compound 2 20 [nM] [68] } \\
\hline${\mathrm{CDK} 2 / \mathrm{A} \mathrm{IC}_{50}}$ & $\mathrm{FP} \mathrm{K}_{\mathrm{i}}$ & $\mathrm{TdCD} \mathrm{K}_{\mathrm{d}}$ & Clinical phase \\
$>10,000$ & 140 & 300 & pre-clinical \\
\hline
\end{tabular}

\section{Type II Inhibitors}

It has been observed that the CDK active site cleft is very spacious and this fact has been widely exploited in drug discovery. It consists of two regions: the front and back clefts, which are separated by the hydrophobic gatekeeper residue (phenylalanine in nearly all CDK members, methionine in CDK10 and CDK11) [69,70]. The residues necessary to adopt DFG-out conformation are the amino acid at the gatekeeper position and the residue immediately prior to the DFG motif (DFG-1) [71].

The conformational plasticity of the DFG-out binding pocket present a huge opportunity to develop many binding site structural variants which hopefully will be trapped and stabilized by inhibitors [72]. This binding pocket has attracted considerable attention, paving the way for the development of type II inhibitors. Type II inhibitors are anticipated not only to address the problem of kinase inhibitor selectivity but also obtain additional therapeutic benefits such as extended drug target residence times, possess better safety profiles and have fewer side effects [73].

Initially, the development of type II inhibitors had been hampered a little because of the notion that only the simplest amino acids, such as threonine or alanine, as a gatekeeper residue allow the back cleft to be accessible, bulky residues (leucine, methionine or phenylalanine) on the other hand stop a potential small molecule inhibitor from entering the back pocket through this internal gate [74]. Recent studies, however, have shown that kinases with bulkier gatekeeper residues are also able to bind type II inhibitors in the DFG-out state [75]. Moreover, cancerous mutations into larger gatekeeper amino acids generally result in kinase activation, thereby stabilizing the active state of the kinase [76-78]. 
Whether kinases with smaller gatekeeper residues still favor the DFG-out motif has yet to be exemplified.

Although, the factors modulating the DFG-out conformation still remain to be elucidated the initial conclusions can be easily drawn. The results reveal that certain protein kinases such as CDK6, receptor-type tyrosine-protein kinase (RTK, FLT3, CD135), coagulation factor II (thrombin) receptor (PAR1), RAC-b serine/threonine-protein kinase (AKT2), mitogen-activated protein kinase 14 (MAPK14, p38a) and bacterial cell membrane nonspecific serine/threonine protein kinase (STK1) favor a classical DFG-out conformation even without the presence of type II inhibitor $[79,80]$, whereas the other inactive, unphosphorylated kinases can be shown to assume the DFG-in conformation [81]. Moreover, Molecular Dynamics (MD) simulations carried out for the Abl tyrosine kinase indicate that DFG binding mode selection might be $\mathrm{pH}$-dependent [82]. Additionally, site-directed mutagenesis (SDM) was used to identify that not only the gatekeeper residue but also the residue located at the $\mathrm{N}$-terminal to the DFG motif play a key role in stabilizing the DFG-out inactive state [71]. Moreover, a comparative analysis of a small library of type II inhibitors showed that over 200 kinases can be targeted, which does not make them intrinsically more selective than type I inhibitors [8]. Moreover, a number of kinases, bound to a type II inhibitor, can exhibit many intermediate states of the DFG-in and DFG-out conformations [83]. The advantages of knowing which and how many enzymes may be targeted by type II inhibitors will be of great value.

Alanine is the most frequently observed amino acid residue at the DFG-1 position (Ala144 in case of CDK2) [84]. However, more data is needed to demonstrate its role in the stabilization of the DFG-out state as one group stated that mutating leucine to cysteine at the DFG-1 position in Mitogen-activated protein kinase 1 (MAPK1) makes it impossible to bind a type II inhibitor by disrupting the DFG-out state [71], while the other one showed that by changing alanine to either cysteine or glycine seem to participate in the stabilization of the DFG-out conformation in CDK2 [85]. Moreover, there are protein kinases which have a cysteine at this position, such as Mitogen-activated protein kinase kinase kinase 7 (MAP3K7, TAK1) which hopefully could bind type II inhibitors [86]. Until more recent information becomes available, it is worth noting that each type of protein kinase should be considered individually, and be limited to the specific case of particular type II inhibitor structure [85].

First attempts to synthesize type II inhibitors of CDK2, the most studied CDK kinase, were based upon their endogenous inhibitors such as the INhibitors of CDK4 (INK4) (p16 and $\mathrm{p} 18$ ) and the CDK interacting proteins/Kinase inhibitory proteins (Cip/Kip) (p21, p27 and p57). The structural studies focused on the interaction of p27 with the CDK2 $\mathrm{N}$-terminal lobe and the cyclin A box revealed that p27 inserts itself into the ATP binding site, thus preventing its conformational activation (PDB entry 1JSU) [87]. The INK4 family inhibitor p18 in the p18-CDK6/cyclin K ternary complex was also found to inactivate the $\mathrm{CDK} /$ cyclin dimer structure by distorting the ATP binding site and misaligning catalytic residues (PDB entry 1G3N) [88]. These observations support the model that the other CDKs may undergo similar inhibitory conformational changes by binding to their respective CDK inhibitors. Numerous peptides and peptidomimetics, based on the sequence alignment of the cyclin-binding motif found in many CDK inhibitory proteins (especially p21 and p27), have been synthesized. Two 8-amino-acid oligopeptidic units H-His-Ala-Lys-ArgArg-Leu-Ile-Phe- $\mathrm{NH}_{2} 21$ and H-Ala-Ala-Abu-Arg-Arg-Leu-Ile- $p$ FPhe- $\mathrm{NH}_{2} 22$ showed the highest growth-inhibitory activities in both the cyclin A competitive binding assay and the $\mathrm{CDK} 2 /$ cyclin A kinase functional assay with $\mathrm{IC}_{50}$ values in the low nanomolar region (Table 4) [89,90]. Another example of the peptidomimetic molecule is MM-D37K 23, derived from $\mathrm{p} 16$, which was found to be the first cyclin D-CDK4/6 alternative class inhibitor in the clinic for colorectal cancer. Collected data will certainly allow interesting comparisons with existing type I inhibitors [91]. 
Table 4. Type II CDK inhibitors under clinical evaluation.

\begin{tabular}{|c|c|c|c|c|c|c|}
\hline & \multicolumn{5}{|c|}{ Kinase $\mathrm{IC}_{50}[\mathrm{nM}]$} & \multirow[b]{2}{*}{ Clinical Phase } \\
\hline & CDK2/A & $\begin{array}{c}\text { Cyclin-Free } \\
\text { CDK2 }\end{array}$ & CDK4/D & CDK6/D & CDK8/C & \\
\hline $\begin{array}{c}\text { H-His-Ala-Lys-Arg-Arg- } \\
\text { Leu-Ile-Phe-NH } 21 \\
\text { [90] }\end{array}$ & 140 & - & - & - & - & pre-clinical \\
\hline $\begin{array}{l}\text { H-Ala-Ala-Abu-Arg- } \\
\text { Arg-Leu-Ile- } p \text { FPhe-NH } \\
22[90]\end{array}$ & 80 & - & - & - & - & pre-clinical \\
\hline MM-D37K 23 [91,92] & - & - & active & active & - & $\begin{array}{c}\text { phase I/II for } \\
\text { Bladder, Gas- } \\
\text { trointestinal, } \\
\text { Glioblastoma, } \\
\text { and Malignant } \\
\text { Melanoma }\end{array}$ \\
\hline Sorafenib 24 [93] & - & - & - & - & 74 & $\begin{array}{l}\text { drug approved } \\
\text { for Renal Cell } \\
\text { Carcinoma, } \\
\text { Hepatocellular } \\
\text { Carcinoma, } \\
\text { AML, and } \\
\text { Advanced } \\
\text { Thyroid } \\
\text { Carcinoma }\end{array}$ \\
\hline Compound 25 [94] & - & - & - & - & 17.4 & pre-clinical \\
\hline K03861 26 [85] & 10,000 & $9.7-50$ & - & - & - & pre-clinical \\
\hline
\end{tabular}

The first small molecule inhibitor which induced the DFG-out motif was Sorafenib 24 (Figure 5), a well-known multikinase type II inhibitor, bound to CDK8/Cyclin C heterodimer complex (PDB entry 3RGF). In case of CDK8 the DFG motif is replaced by a unique Asp-Met-Gly tripeptide motif (DMG) [93]. Sorafenib has been found to disrupt mitogen-activated protein kinase (Ras-MAPK) signaling in many cell-based assays, such as colon, liver, kidney, lung, and breast cancer cell lines $[95,96]$. The function of Ras-MAPK pathway is to transduce signals from the extracellular receptor to the DNA in the cell nucleus where specific genes are activated for cell growth, division and differentiation [97]. Structure-guided modification of Sorafenib resulted in a series of potent CDK8 inhibitors stabilizing the DMG-out conformation such as compound 25 (Figure 5). However, these inhibitors (including Sorafenib) demonstrated weak activity in cellular assays (they neither suppressed the Wnt/ $\beta$-catenin pathway nor phosphorylated Signal transducer and activator of transcription 1 (STAT1) at Ser727). These findings also suggest that type II inhibitors target the inactive form of CDK8 which is poorly accessible in cells due to the fact that it either forms the Mediator or the kinase-module [94,98]. Most recent data show that the antitumor efficacy of Sorafenib can be enhanced by the addition of Flavopiridol in both Sorafenib-sensitive and Sorafenib-resistant hepatocellular carcinoma (HCC) cell lines. The enhancing effects result from the synergistic effect of co-targeting two different biological mechanisms: CDKs (Flavopiridol) and the Ras-MAPK pathway (Sorafenib), both being linked to the suppression of Mcl-1 expression [99]. 
<smiles>CNC(=O)c1cc(Oc2ccc(NC(=O)Nc3ccc(Cl)c(C(F)(F)F)c3)cc2)ccn1</smiles>

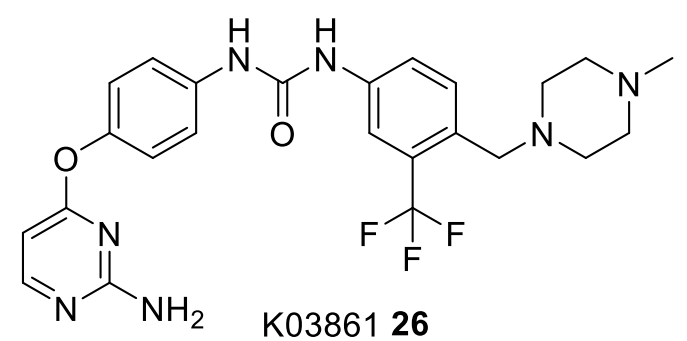<smiles>CNc1nccc(N2CC[C@@H](NC(=O)Nc3ccc(CN4CCOCC4)c(C(F)(F)F)c3)C2)n1</smiles>

\section{Compound 25}

Figure 5. Chemical structures of some of the most studied type II CDK inhibitors.

Another example of inhibitor able to adopt the DFG-out conformation is K03861 (AUZ454) 26 (Figure 5) an aminopyrimidine-phenyl urea inhibitor. This is a type II CDK2 inhibitor with $\mathrm{K}_{\mathrm{d}}$ values of $50 \mathrm{nM}, 18.6 \mathrm{nM}, 15.4 \mathrm{nM}$, and $9.7 \mathrm{nM}$ for CDK2 (wild type), CDK2(C118L), CDK2(A144C), and CDK2(C118L/A144C), respectively (Table 4). The cocrystal structure of K03861 bound to cyclin-free CDK2 exhibit a type II binding mode with the DFG-out state (PDB entry 1b38). Further analysis of this compound, obtained from kinetic binding experiments, revealed slow off-rates, meaning that compounds exhibiting slow dissociation rates could be considered as a clinically important and statistically significant benefit to patients since they interact with a kinase for much longer [85].

\section{Type III Inhibitors}

This type of inhibitors are compounds which make specific interactions with an exclusive pocket, known as the back pocket of the kinase, which is adjacent to the ATP binding site. Type I/II kinase inhibitors are very sensitive to the gatekeeper mutations affecting the residues within the ATP pocket, the region that has been recognized as responsible for acquired resistance to type I and II kinase inhibitors [100,101].

PD184352 (CI-1040), a selective oral mitogen-activated protein kinase kinase $1 / 2$ (MAP2K1/2, MEK1/2) inhibitor, was the first type III inhibitor to enter clinical trials, that laid the groundwork for the discovery of additional non-ATP-competitive inhibitors [102]. However, no such molecule has been reported in case of type III CDK inhibitors.

\section{Type IV Inhibitors}

Type IV inhibitors have been defined as compounds which bind to unique structural features remote from the ATP binding pocket and are able to interact with these allosteric regions by stabilizing inactive conformations. The allosteric pocket of type IV inhibitors can be located anywhere within the kinase, with one exception for the hydrophobic pocket close to the ATP-binding site which is targeted by type III inhibitors [103]. Potential compounds able to allosterically regulate kinase enzymatic activity will offer the possibility of achieving distinctive advantages which could make them very valuable. Type IV inhibitors do not need to interfere with the phosphorylation of all native substrates but only some, allowing them to block the kinase functions responsible for a particular disease but at the same time preserving their positive functions. However, it is still very difficult to determine what sites are necessary for a certain biological function. The arduous investigation to predict potential allosteric kinase hot spots identified ten different sites outside the ATP site that 
can be utilized in future development of type IV kinase inhibitors, and their applications in regulating kinase activity in a variety of disease states $[4,104,105]$.

Based on structural features of CDK2, a novel allosteric inhibitor, 8-anilino-1-naphthalene sulfonate (ANS) 27, was discovered (Figure 6).<smiles>O=S(=O)(O)c1cccc2cccc(Nc3ccccc3)c12</smiles>

ANS 27

Figure 6. Chemical structure of 8-anilino-1-naphthalene sulfonate (ANS) the most studied type IV CDK inhibitor.

It was found to bind to monomeric CDK2 by exploring a cavity very close to the DFG region which results in a structural transformation able to disrupt interactions with the CDK2 activator cyclin A. The activation loop adopts the active DFG-in conformation (PDB entry 3PXF). Consistent with its weak binding affinity to CDK2 $\left(\mathrm{K}_{\mathrm{d}}=37 \mu \mathrm{M}\right)$ ANS can be easily displaced from the enzyme by cyclin A with an $\mathrm{EC}_{50}$ value of $0.6 \mu \mathrm{M}$. In addition, ANS was found to inhibit the active, phosphorylated CDK2/cyclin A dimer complex with a poor $\mathrm{IC}_{50}$ value of $91 \mu \mathrm{M}$ (Table 5). It has been concluded that inhibitors with an ANS-like binding mode must interact more efficiently with monomeric CDK2 to noticeably improve their binding affinity, in order to inhibit complex formation with cyclins [106].

Table 5. Selected biological data obtained from different experiments with ANS which demonstrate that it targets monomeric CDK2.

\begin{tabular}{cccc}
\hline & ANS 27 [nM] [106] & & \\
\cline { 1 - 3 } CDK2/A IC 5 50 & $\begin{array}{c}\text { Cyclin-Free CDK2 } \\
\mathbf{K}_{\mathbf{d}}\end{array}$ & $\begin{array}{c}\text { ANS Displacement } \\
\text { EC }_{\mathbf{5 0}}\end{array}$ & Clinical Phase \\
\cline { 2 - 3 } 91,000 & 37,000 & 600 & pre-clinical \\
\hline
\end{tabular}

\section{Type V Inhibitors}

The preparation of type $\mathrm{V}$ inhibitors is considered as a new method to discover compounds which target both the ATP-binding site as well as distinct structural elements unique to each protein kinase in order increase their potency and selectivity. This group of compounds refers to bi-substrate inhibitors. However, the key problem relating to this class of agents is maintaining a balance between potency and selectivity in order to modulate their cellular activity or physicochemical properties [107,108]. A series of highly selective and potent type $\mathrm{V}$ inhibitors targeting tyrosine and serine/threonine kinases have been synthesized [109-112], but as of yet, no such molecule has been reported to be active against CDK family members.

\section{Type VI Inhibitors}

In recent years, there has been rapid progress made in the development of kinase inhibitors which can make covalent, very often irreversible, bond with the kinase active pocket (Figure 7). 
<smiles>[Y16][Z11]([H])([H])[H]</smiles>

Figure 7. Chemical structures of some of the most studied type VI CDK inhibitors.

The initial research findings, relating to the covalent-binding drugs, indicated that some of these agents can be beneficial to our health and some not necessarily. For instance, aspirin binds with a serine residue of the cyclooxygenase-1 (COX-1) enzyme, by forming covalent adducts, hence preventing the production of proinflammatory cytokines [113]. In contrast, paracetamol metabolizes into highly reactive radicals, although only in about $3 \%$, when overdosed can cause oxidative stress, by forming toxic covalent adducts with liver proteins [114]. However, the most recent advances in Computational Biosciences have made it possible to design compounds with augmented selectivity and efficacy, and limited adverse effects.

Type VI inhibitors utilize chemical properties of type I-IV inhibitors, but they possess additional electrophilic groups (known as warheads) which mainly react with a nucleophilic cysteine residue in the active site (occasionally they also target lysine and tyrosine residues). Irreversible kinase inhibitors are meant to limit drug resistance given by protein kinase mutations, as well as overcome the competition from endogenous ATP. The adduct is generated in the Michael reaction through an acrylamide group (electrophilic warhead) which favors the formation of bonds with cysteine residues. It is thought that by lowering the reactivity of the warhead of type VI inhibitor to generate new shorter-acting reversible type IV agents could reduce their toxicity and off-target reactivity [115].

The first irreversible kinase inhibitor is THZ1 14 (Figure 7) which covalently binds to a cysteine residue (Cys312) in the ATP binding pocket (PDB entry 1UA2). This compound inhibits CDK7. At higher concentration it also demonstrates some activity against closely related kinases CDK12 and CDK13 (Table 6) [116]. Based on the THZ1 scaffold a new more selective covalent inhibitors, SY-1365 28 and THZ531 29 (Figure 7), have been identified. SY-1365 is currently being investigated for the treatment of ovarian and breast cancers (NCT03134638) [117], whereas THZ531 turned out to be a selective covalent inhibitor of CDK12/13 [118] (Table 6). To further optimize the structure of THZ1-like inhibitors another generation of irreversible CDK inhibitors, E9 30 (Figure 7), has been proposed. The findings show that E9 can overcome a common problem of resistance to the THZ1-like agents by ABC transporter-mediated drug efflux, and it covalently targets CDK12 (Table 6) [119]. 
Table 6. Type VI CDK inhibitors under clinical evaluation.

\begin{tabular}{|c|c|c|c|c|c|c|}
\hline & \multicolumn{5}{|c|}{ Kinase $\mathrm{IC}_{50}[\mathrm{nM}]$} & \multirow{2}{*}{ Clinical Phase } \\
\hline & CDK2/A & CDK7/H/MAT1 & CDK9/T1 & CDK12/K & CDK13/K & \\
\hline $\begin{array}{c}\text { THZ531 } 29 \\
\text { [118] }\end{array}$ & - & 8500 & 10500 & 158 & 69 & $\begin{array}{c}\text { phase } \\
\text { II-observational } \\
\text { study for the } \\
\text { patients-derived } \\
\text { High Grade Serous } \\
\text { Ovarian Cancer } \\
\text { (HGSOC) } \\
\text { organoids } \\
\text { NCT04555473 }\end{array}$ \\
\hline THZ1 14 [116] & - & 3.2 & - & $>1000$ & $>1000$ & pre-clinical \\
\hline SY-1365 28 [117] & - & 20 & - & - & - & $\begin{array}{c}\text { phase I for } \\
\text { Advanced Solid } \\
\text { Tumors, Ovarian, } \\
\text { and Breast Cancer } \\
\text { NCT03134638 }\end{array}$ \\
\hline E9 30 [119] & 932 & 1210 & 23.9 & - & - & pre-clinical \\
\hline
\end{tabular}

Comparative studies of type VI inhibitors targeting other kinases, such as Ibrutinib or Afatinib, with type I and type II inhibitors demonstrated long-term clinical benefits of early treatment of patients with chronic lymphocytic leukemia (CLL), small lymphocytic lymphoma (SLL) [120] and lung cancer [121]. However, the research aimed at targeting only one amino acid (cysteine) can lead to a single point mutation resulting in acquired resistance to this particular agent. Therefore, the latest studies are focused on the development of type VI CDK inhibitors able to utilize the reactivity of other nucleophilic amino acids, such as lysine, tyrosine or even aspartic acid residues [115,122]. Hopefully, this theoretical data will soon generate new type VI CDK inhibitors.

\section{Targeted Protein Degradation (TPD)}

Recent advances in medical modalities gave rise to an appealing and promising technology known as Targeted Protein Degradation (TPD). TPD is a highly efficient method for selectively targeting proteins for removal from the cell, rather than inhibiting their activity. It is anticipated that, by using this method, toxic and disease-causing proteins could be depleted from cells under the potentially effective low-dose treatment. Small molecules able to induce degradation of target proteins can be divided into three major classes based on the structure of the compounds and their mechanism of action [123]. Single-ligand molecules able to create a direct interaction with the target protein to induce degradation belong to the first class of compounds. This group of compounds is represented by the aforementioned Fulvestrant, a selective estrogen receptor downregulator (SERD) which reduces the estrogen receptor- $\alpha(E R \alpha)$ protein level [124]. However, this approach is limited to the finite number of target proteins.

Compounds that interact with E3 ubiquitin ligase to modulate substrate selectivity to modulate substrate selectivity are known as E3 modulators or molecular glues. The processes by which degradation of proteins is induced include: ubiquitination, targeting to the proteasome, proteolysis and functional silencing. Molecular glues act substoichiometrically to facilitate rapid depletion of previously inaccessible proteins, but have mostly been identified somewhat serendipitously [125]. The first molecular glue was thalidomide which was identified to interact with CRBN gene (Cereblon) [126], a substrate recognition subunit of the Cullin-RING E3 ubiquitin ligase (CRL4) [127].

In relation to CDK molecular glues, the first compound acting as molecular glue degrader is $R$-CR8 31, a pan-selective cyclin-dependent kinase (CDK) inhibitor (very similar to $R$-Roscovitine) (Figure 8) [128]. $R$-CR8 binds to the CDK12/cyclin K dimer, the 
resultant surface-exposed 2-pyridyl moiety facilitates CDK12/cyclin K complex formation with DDB1, the CUL4 adaptor protein, by circumventing the necessity for a substrate receptor and triggers rapid proteasomal degradation of cyclin K [129].<smiles>CC(CO)Nc1nc(NCc2ccc(-c3ccccn3)cc2)c2ncn(C(C)C)c2n1</smiles>

\section{$R-C R 831$}

Figure 8. Chemical structure of CR8. A surface-exposed 2-pyridyl moiety of CR8 is responsible for glue degrader properties.

The third class encompasses the chimeric small molecules, where an E3 ligase component and a protein of interest are linked to form a new and unique molecule. This group of compounds was developed under different names such as PROteolysis TArgeting Chimeras (PROTACs) and Specific and Non-genetic IAP-dependent Protein Erasers (SNIPERs). They target different proteins, but their mechanism of action is almost identical. Both, PROTACs and SNIPERs initiate the degradation of targeted protein by linking the protein of interest to an E3 ubiquitin ligase using the cell's natural ubiquitin proteasome pathway (UPS) [130].

In relation to CDK kinases a series of PROTECs molecules have been reported. First dual CDK4/ 6 degraders 32, synthesized by linking Pomalidomide and Palbociclib, were reported by Burgess which efficiently degraded $\mathrm{CDK} 4 / 6$ with $\mathrm{DC}_{50}$ values ranging from 20-50 nM (Figure 9).
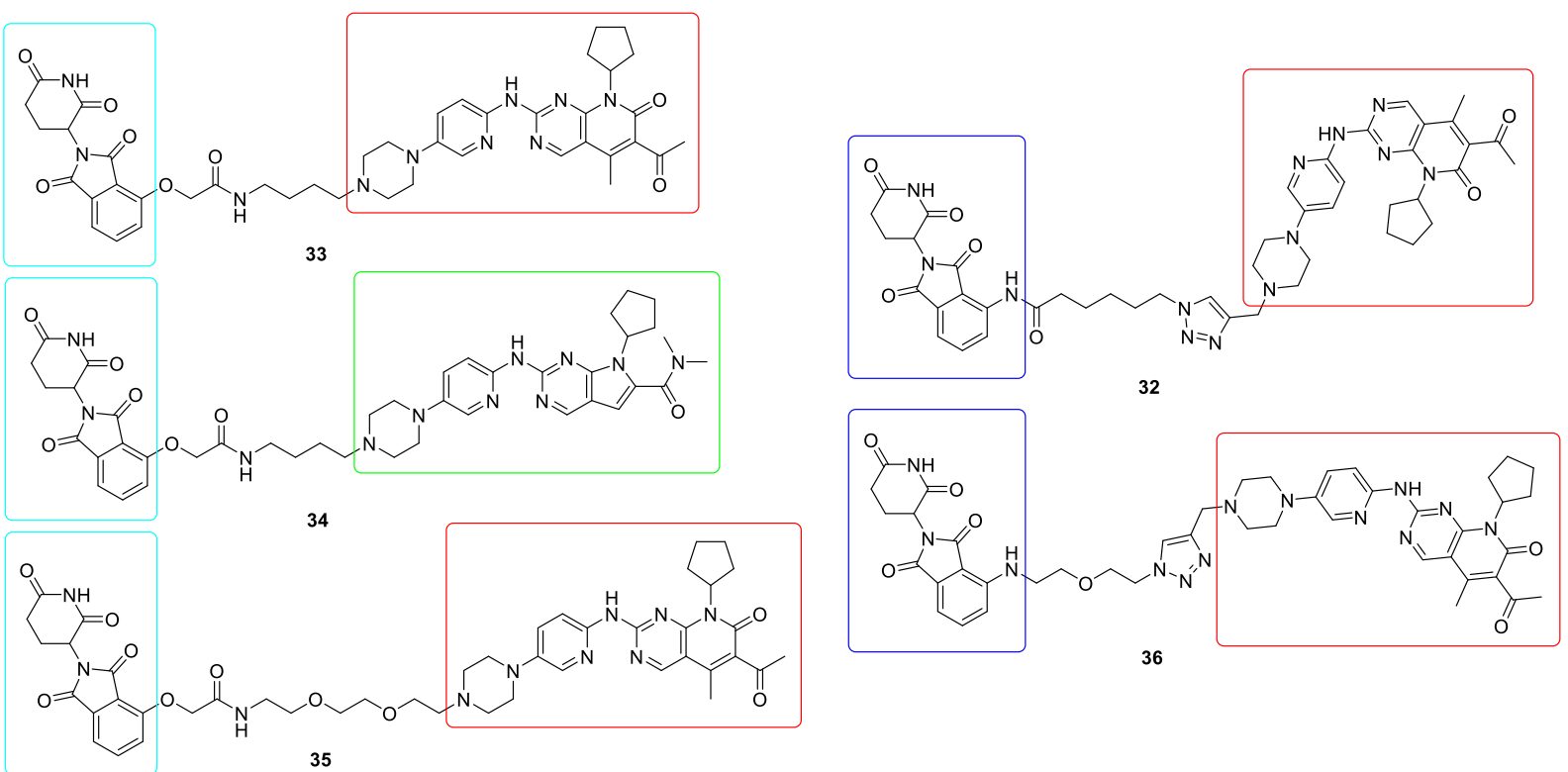

Figure 9. Chemical structures of CDK4/6 PROteolysis TArgeting Chimeras (PROTACs). Red rectangle denotes the palbociclib moiety, green rectangle denotes the ribociclib moiety, light blue rectangle denotes the thalidomide moiety and dark blue rectangle denotes the pomalidomide moiety.

However, these compounds were not active in cells with overexpressed CDK4/6 [131]. Another group identified both dual CDK4/ 6 degraders 33 (based on Thalidomide and Palbociclib), as well as selective CDK4 34 (based on Thalidomide and Ribociclib) and 
CDK6 35 (based on Thalidomide and Palbociclib) degraders (Figure 9). These compounds exhibited good target degradation at $100 \mathrm{nM}$ and showed more profound antiproliferative activities $[132,133]$. Very promising CDK6 degrader $\mathbf{3 6}$ was synthesized by linking Pomalidomide and Palbociclib (Figure 9). It possessed high CDK6 degradation capacity with a $\mathrm{DC}_{50}$ value of $2.1 \mathrm{nM}$. Moreover, it inhibited the proliferation of hematopoietic cancer cells, even with copy-amplified/mutated forms of CDK6 [134]. However, it is worth noting that their impact is still limited due to resistance development, which is the biggest challenge for PROTAC-based therapies at the moment [135].

As the effectiveness of traditional CDK8 inhibitors in the treatment of numerous cancers has yet to be confirmed, hence the need to elaborate new PROTACs for degrading the protein CDK8 became a driving force to overcome these shortcomings [136]. Cortistatin A was used to develop new derivatives. One of these compounds JH-XI-10-02 (37) is a potent $\mathrm{CDK} 8$ degrader (Figure 10). Its efficacy was verified by carrying out the degradation experiments in Jurkat and CRBN knockout Molt14 cells [137]. The synthesis of CDK8 degraders will definitely help to clarify whether targeting CDK8 is an effective strategy for treating cancer.

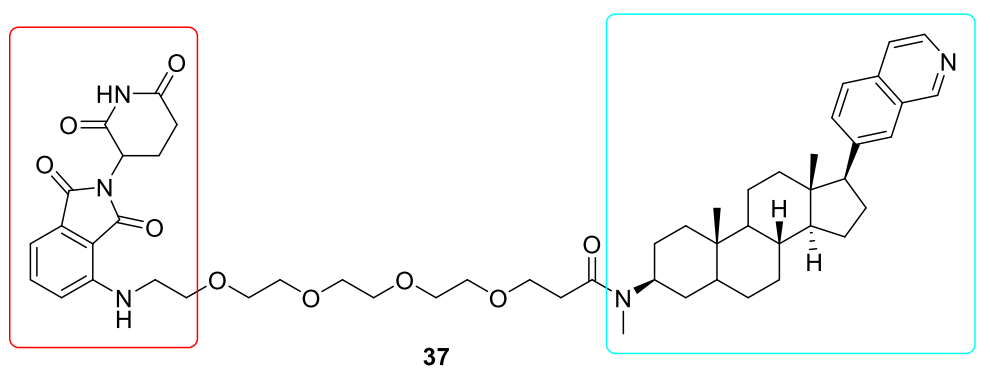

Figure 10. Chemical structure of CDK8 PROTAC. Red rectangle denotes the pomalidomide moiety, light blue rectangle denotes the Cortistatin A derivative JH-VIII-49 moiety.

CDK9 forms a part of the positive transcription elongation factor $b$ ( $\mathrm{P}-\mathrm{TEFb})$ complex which together with cyclin $\mathrm{T}$ is responsible for the transcription elongation. CDK9 was found to be present in all tissues and numerous malignancies [138]. Due to the fact that CDK9 shares a high level of conservation sequence with other CDK members, it is difficult to obtain satisfactory selectivity [139]. In order to develop effective CDK9-targeting PROTAC it is necessary to identify lysine residues which can be targeted for ubiquitination and degradation [140]. The first selective CDK9 degrader 38 was developed on the basis of aminopyrazole derivative and Thalidomide (Figure 11). This CDK9 degrader reduced CDK9 protein activity in HCT116 cells by 56 and $65 \%$ at 10 and $20 \mu \mathrm{M}$, respectively, without affecting other CDKs [141]. Another CDK9 degrader, THAL-SNS-032 39 was developed by conjugating pan-selective CDK inhibitor SNS-032 and Pomalidomide (Figure 11). It selectively degraded CDK9 with a $99 \% \mathrm{D}_{\max }$ at $250 \mathrm{nM}$ in MOLT 4 cells after $6 \mathrm{~h}$ treatment. Moreover, THAL-SNS-032 exhibited slower dissociation rates [142]. Yet another CDK9 degrader $\mathbf{4 0}$ was generated by conjugation of the natural compound Wogonin to Pomalidomide (Figure 11). This PROTAC induced the rapid degradation and showed more potency $\left(\mathrm{IC}_{50}=17 \pm 1.9 \mu \mathrm{M}\right)$ than Wogonin $\left(\mathrm{IC}_{50}=30 \pm 3.5 \mu \mathrm{M}\right)$ in MCF7 cells [143]. 

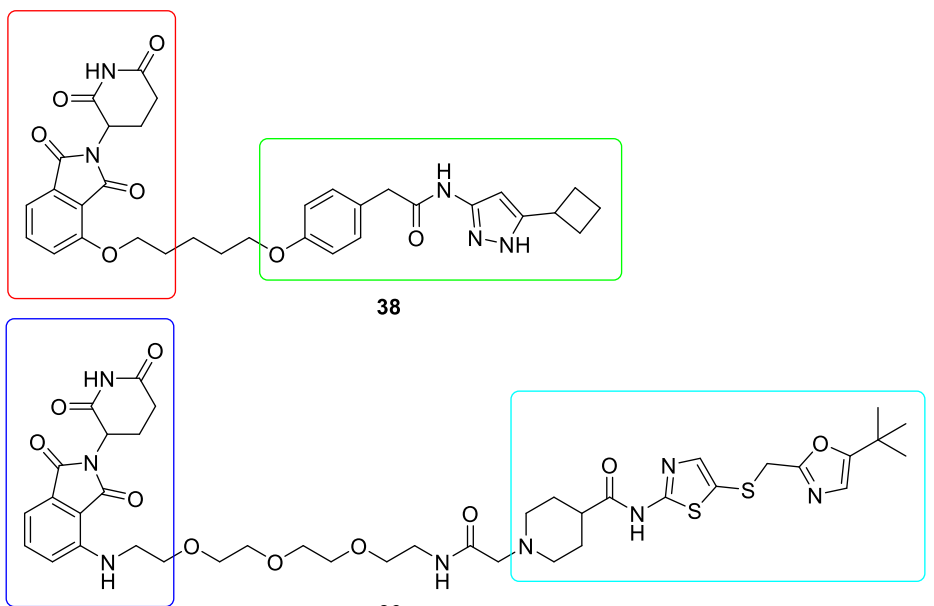

39

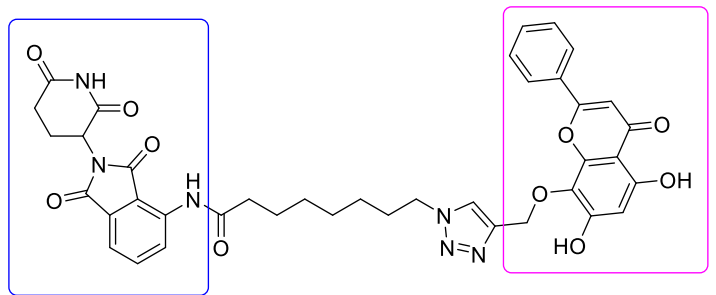

40

Figure 11. Chemical structures of CDK9 PROTACs. Red rectangle denotes the Thalidomide moiety, dark blue rectangle denotes the Pomalidomide moiety, green rectangle denotes the aminopyrazole derivative moiety, light blue rectangle denotes the SNS-032 moiety and violet rectangle denotes the Wogonin moiety.

\section{Conclusions}

Cyclin-dependent kinases (CDKs) have unique tissue specific functions and dysregulation of CDKs and their cyclin partners is observed in a range of tumor types, and some of them have emerged as promising therapeutic targets in cancer. The major challenges in the CDK-targeted drug discovery are selectivity and bad responses, or resistance to treatments. However, the latest advances in the field provide encouragement that highly selective and potent inhibitors of human cyclin-dependent kinases with favorable pharmacokinetic properties will be identified.

Author Contributions: Conceptualization, P.Ł.; Funding acquisition, I.G.; Visualization, I.B.-B.; Writing—original draft, P.Ł.; Writing—review \& editing, K.K., I.G. All authors have read and agreed to the published version of the manuscript.

Funding: This work was supported by statutory budget of Department of Medical Chemistry Pomeranian Medical University in Szczecin.

Institutional Review Board Statement: Not applicable.

Informed Consent Statement: Not applicable.

Data Availability Statement: Not applicable.

Conflicts of Interest: The authors declare they have no actual or potential competing financial interests.

Ethical Approval: The study was performed in accordance with the Declaration of Helsinki.

\section{References}

1. Pavletich, N.P. Mechanisms of cyclin-dependent kinase regulation: Structures of cdks, their cyclin activators, and cip and INK4 inhibitors. J. Mol. Biol. 1999, 287, 821-828. [CrossRef]

2. Cohen, P. Protein kinases-The major drug targets of the twenty-first century? Nat. Rev. Drug Discov. 2002, 1, 309-315. [CrossRef] 
3. Marra, A.; Curigliano, G. Are all cyclin-dependent kinases 4/6 inhibitors created equal? NPJ Breast Cancer 2019, 5, 27. [CrossRef] [PubMed]

4. Wu, P.; Clausen, M.H.; Nielsen, T.E. Allosteric small-molecule kinase inhibitors. Pharmacol. Ther. 2015, 156, 59-68. [CrossRef] [PubMed]

5. Morgan, D.O. The Cell Cycle: Principles of Control, 1st ed.; New Science Press: London, UK, 2007.

6. Patrick, G.N.; Zukerberg, L.R.; Nikolic, M.; De La Monte, S.; Dikkes, P.; Tsai, L.-H. Conversion of p35 to p25 deregulates Cdk5 activity and promotes neurodegeneration. Nat. Cell Biol. 1999, 402, 615-622. [CrossRef] [PubMed]

7. Osuga, H.; Osuga, S.; Wang, F.; Fetni, R.; Hogan, M.J.; Slack, R.S.; Hakim, A.M.; Ikeda, J.-E.; Park, D.S. Cyclin-dependent kinases as a therapeutic target for stroke. Proc. Natl. Acad. Sci. USA 2000, 97, 10254-10259. [CrossRef] [PubMed]

8. Zhao, Z.; Wu, H.; Wang, L.; Liu, Y.; Knapp, S.; Liu, Q.; Gray, N.S. Exploration of Type II Binding Mode: A Privileged Approach for Kinase Inhibitor Focused Drug Discovery? ACS Chem. Biol. 2014, 9, 1230-1241. [CrossRef] [PubMed]

9. Rabiller, M.; Getlik, M.; Klüter, S.; Richters, A.; Tückmantel, S.; Simard, J.R.; Rauh, D. Proteus in the World of Proteins: Conformational Changes in Protein Kinases. Arch. Pharm. 2010, 343, 193-206. [CrossRef]

10. Baumli, S.; Lolli, G.; Lowe, E.D.; Troiani, S.; Rusconi, L.; Bullock, A.N.; Debreczeni, J.É.; Knapp, S.; Johnson, L.N. The structure of P-TEFb (CDK9/cyclin T1), its complex with flavopiridol and regulation by phosphorylation. EMBO J. 2008, 27, 1907-1918. [CrossRef]

11. Chao, S.-H.; Fujinaga, K.; Marion, J.E.; Taube, R.; Sausville, E.A.; Senderowicz, A.M.; Peterlin, B.M.; Price, D.H. Flavopiridol Inhibits P-TEFb and Blocks HIV-1 Replication. J. Biol. Chem. 2000, 275, 28345-28348. [CrossRef] [PubMed]

12. A Carlson, B.; Dubay, M.M.; A Sausville, E.; Brizuela, L.; Worland, P.J. Flavopiridol induces G1 arrest with inhibition of cyclin-dependent kinase (CDK) 2 and CDK4 in human breast carcinoma cells. Cancer Res. 1996, 56, 2973-2978. [PubMed]

13. De Azevedo, W.F.; Mueller-Dieckmann, H.J.; Schulzegahmen, U.; Worland, P.J.; A Sausville, E.; Kim, S.H. Structural basis for specificity and potency of a flavonoid inhibitor of human CDK2, a cell cycle kinase. Proc. Natl. Acad. Sci. USA 1996, 93, 2735-2740. [CrossRef]

14. E Kahn, M.; Senderowicz, A.; A Sausville, E.; E Barrett, K. Possible mechanisms of diarrheal side effects associated with the use of a novel chemotherapeutic agent, flavopiridol. Clin. Cancer Res. 2001, 7, 343.

15. Stadler, W.M.; Vogelzang, N.J.; Amato, R.; Sosman, J.; Taber, D.; Liebowitz, D.; Vokes, E.E. Flavopiridol, A Novel CyclinDependent Kinase Inhibitor, in Metastatic Renal Cancer: A University of Chicago Phase II Consortium Study. J. Clin. Oncol. 2000, 18, 371. [CrossRef] [PubMed]

16. Brown, J.R. Chronic Lymphocytic Leukemia: A Niche for Flavopiridol? Clin. Cancer Res. 2005, 11, 3971-3973. [CrossRef]

17. De Azevedo, W.F., Jr.; Gaspar, R.T.; Canduri, F.; Camera, J.C., Jr.; da Silveira, N.J.F.J.B. Molecular model of cyclin-dependent kinase 5 complexed with roscovitine. Biochem. Biophy. Res. Commun. 2002, 297, 1154-1158. [CrossRef]

18. Blachly, J.S.; Byrd, J.C. Emerging drug profile: Cyclin-dependent kinase inhibitors. Leuk. Lymphoma 2013, 54, 2133-2143. [CrossRef] [PubMed]

19. Pippin, J.W.; Qu, Q.; Meijer, L.; Shankland, S.J. Direct in vivo inhibition of the nuclear cell cycle cascade in experimental mesangial proliferative glomerulonephritis with Roscovitine, a novel cyclin-dependent kinase antagonist. J. Clin. Investig. 1997, 100, 2512-2520. [CrossRef] [PubMed]

20. Hoogendijk, A.J.; Roelofs, J.J.T.H.; Duitman, J.; Van Lieshout, M.H.P.; Blok, D.C.; Van Der Poll, T.; Wieland, C.W. R-roscovitine Reduces Lung Inflammation Induced by Lipoteichoic Acid and Streptococcus pneumoniae. Mol. Med. 2012, 18, $1086-1095$. [CrossRef] [PubMed]

21. Schang, L.M.; Bantly, A.; Knockaert, M.; Shaheen, F.; Meijer, L.; Malim, M.H.; Gray, N.S.; Schaffer, P.A. Pharmacological CyclinDependent Kinase Inhibitors Inhibit Replication of Wild-Type and Drug-Resistant Strains of Herpes Simplex Virus and Human Immunodeficiency Virus Type 1 by Targeting Cellular, Not Viral, Proteins. J. Virol. 2002, 76, 7874-7882. [CrossRef] [PubMed]

22. Patrick, C.; Crews, L.; Desplats, P.; Dumaop, W.; Rockenstein, E.; Achim, C.L.; Everall, I.P.; Masliah, E. Increased CDK5 Expression in HIV Encephalitis Contributes to Neurodegeneration via Tau Phosphorylation and Is Reversed with Roscovitine. Am. J. Pathol. 2011, 178, 1646-1661. [CrossRef]

23. Cicenas, J.; Kalyan, K.; Sorokinas, A.; Stankunas, E.; Levy, J.; Meskinyte, I.; Stankevicius, V.; Kaupinis, A.; Valius, M. Roscovitine in cancer and other diseases. Ann. Transl. Med. 2015, 3, 135.

24. Parry, D.; Guzi, T.; Shanahan, F.; Davis, N.; Prabhavalkar, D.; Wiswell, D.; Seghezzi, W.; Paruch, K.; Dwyer, M.P.; Doll, R.; et al. Dinaciclib (SCH 727965), a Novel and Potent Cyclin-Dependent Kinase Inhibitor. Mol. Cancer Ther. 2010, 9, 2344-2353. [CrossRef] [PubMed]

25. Flynn, J.; Jones, J.; Johnson, A.J.; Andritsos, L.; Maddocks, K.; Jaglowski, S.; Hessler, J.; Grever, M.R.; Im, E.; Zhou, H.; et al. Dinaciclib is a novel cyclin-dependent kinase inhibitor with significant clinical activity in relapsed and refractory chronic lymphocytic leukemia. Leukemia 2015, 29, 1524-1529. [CrossRef]

26. Yakisich, J.S.; Vita, M.F.; Siden, Å.; Tasat, D.R.; Cruz, M. Strong inhibition of replicative DNA synthesis in the developing rat cerebral cortex and glioma cells by roscovitine. Investig. New Drugs 2009, 28, 299-305. [CrossRef] [PubMed]

27. Le Tourneau, C.; Faivre, S.; Laurence, V.; Delbaldo, C.; Vera, K.; Girre, V.; Chiao, J.; Armour, S.; Frame, S.; Green, S.R.; et al. Phase I evaluation of seliciclib (R-roscovitine), a novel oral cyclin-dependent kinase inhibitor, in patients with advanced malignancies. Eur. J. Cancer 2010, 46, 3243-3250. [CrossRef] 
28. Brasca, M.G.; Amboldi, N.; Ballinari, D.; Cameron, A.; Casale, E.; Cervi, G.; Colombo, M.; Colotta, F.; Croci, V.; D'Alessio, R.; et al. Identification of N,1,4,4-Tetramethyl-8-\{[4-(4-methylpiperazin-1-yl)phenyl]amino\}-4,5-dihydro-1H-pyrazolo [4,3-h]quinazoline-3carboxamide (PHA-848125), a Potent, Orally Available Cyclin Dependent Kinase Inhibitor. J. Med. Chem. 2009, 52, 5152-5163. [CrossRef] [PubMed]

29. Milciclib. Available online: http://www.tizianalifesciences.com/drug-pipeline/milciclib/ (accessed on 20 January 2021).

30. Rocca, A.; Farolfi, A.; Bravaccini, S.; Schirone, A.; Amadori, D. Palbociclib (PD 0332991): Targeting the cell cycle machinery in breast cancer. Expert Opin. Pharmacother. 2014, 15, 407-420. [CrossRef] [PubMed]

31. Samson, K. LEE011 CDK Inhibitor Showing Early Promise in Drug-Resistant Cancers. Oncol. Times 2014, 36, 39-40. [CrossRef]

32. Diéras, V.; Harbeck, N.; Joy, A.A.; Gelmon, K.; Ettl, J.; Verma, S.; Lu, D.R.; Gauthier, E.; Schnell, P.; Mori, A.; et al. Palbociclib with Letrozole in Postmenopausal Women with ER+/HER2- Advanced Breast Cancer: Hematologic Safety Analysis of the Randomized PALOMA-2 Trial. Oncologist 2019, 24, 1514. [CrossRef]

33. Sosman, J.A.; Kittaneh, M.; Lolkema, M.P.J.K.; Postow, M.A.; Schwartz, G.; Franklin, C.; Matano, A.; Bhansali, S.; Parasuraman, S.; Kim, K. A phase 1b/2 study of LEE011 in combination with binimetinib (MEK162) in patients with NRAS-mutant melanoma: Early encouraging clinical activity. J. Clin. Oncol. 2014, 32, 9009. [CrossRef]

34. Corbel, C.; Zhang, B.; Le Parc, A.; Baratte, B.; Colas, P.; Couturier, C.; Kosik, K.S.; Landrieu, I.; Le Tilly, V.; Bach, S. Tamoxifen Inhibits CDK5 Kinase Activity by Interacting with p35/p25 and Modulates the Pattern of Tau Phosphorylation. Chem. Biol. 2015, 22, 472-482. [CrossRef]

35. Maccallum, D.E. Seliciclib (CYC202, R-Roscovitine) Induces Cell Death in Multiple Myeloma Cells by Inhibition of RNA Polymerase II-Dependent Transcription and Down-regulation of Mcl-1. Cancer Res. 2005, 65, 5399-5407. [CrossRef] [PubMed]

36. Stevens, A.; Maupin, M.K. 5,6-Dichloro-1- $\beta$-D-ribofuranosylbenzimidazole inhibits a HeLa protein kinase that phosphorylates an RNA polymerase II-derived peptide. Biochem. Biophys. Res. Commun. 1989, 159, 508-515. [CrossRef]

37. Zhu, Y.; Pe'Ery, T.; Peng, J.; Ramanathan, Y.; Marshall, N.; Marshall, T.; Amendt, B.; Mathews, M.B.; Price, D.H. Transcription elongation factor P-TEFb is required for HIV-1 Tat transactivation in vitro. Genes Dev. 1997, 11, 2622-2632. [CrossRef]

38. Sedlacek, H. Mechanisms of action of flavopiridol. Crit. Rev. Oncol. 2001, 38, 139-170. [CrossRef]

39. Montagnoli, A.; Valsasina, B.; Croci, V.; Menichincheri, M.; Rainoldi, S.; Marchesi, V.; Tibolla, M.; Tenca, P.; Brotherton, D.; Albanese, C.; et al. A Cdc7 kinase inhibitor restricts initiation of DNA replication and has antitumor activity. Nat. Chem. Biol. 2008, 4, 357-365. [CrossRef]

40. Bach, S.; Knockaert, M.; Reinhardt, J.; Lozach, O.; Schmitt, S.; Baratte, B.; Koken, M.; Coburn, S.P.; Tang, L.; Jiang, T.; et al. Roscovitine Targets, Protein Kinases and Pyridoxal Kinase. J. Biol. Chem. 2005, 280, 31208-31219. [CrossRef]

41. Vassilev, L.T.; Tovar, C.; Chen, S.; Knezevic, D.; Zhao, X.; Sun, H.; Heimbrook, D.C.; Chen, L. Selective small-molecule inhibitor reveals critical mitotic functions of human CDK1. Proc. Natl. Acad. Sci. USA 2006, 103, 10660-10665. [CrossRef] [PubMed]

42. Zhang, D.; Mita, M.; Shapiro, G.I.; Poon, J.; Small, K.; Tzontcheva, A.; Kantesaria, B.; Zhu, Y.; Bannerji, R.; Statkevich, P. Effect of aprepitant on the pharmacokinetics of the cyclin-dependent kinase inhibitor dinaciclib in patients with advanced malignancies. Cancer Chemother. Pharmacol. 2012, 70, 891-898. [CrossRef] [PubMed]

43. Fry, D.W.; Harvey, P.J.; Keller, P.R.; Elliott, W.L.; Meade, M.; Trachet, E.; Albassam, M.; Zheng, X.; Leopold, W.R.; Pryer, N.K.; et al. Specific inhibition of cyclin-dependent kinase 4/6 by PD 0332991 and associated antitumor activity in human tumor xenografts. Mol. Cancer 2004, 3, 1427.

44. Tripathy, D.; Bardia, A.; Sellers, W.R. Ribociclib (LEE011): Mechanism of Action and Clinical Impact of This Selective CyclinDependent Kinase 4/6 Inhibitor in Various Solid Tumors. Clin. Cancer Res. 2017, 23, 3251-3262. [CrossRef]

45. Gelbert, L.M.; Cai, S.; Lin, X.; Sanchez-Martinez, C.; Del Prado, M.; Lallena, M.J.; Torres, R.; Ajamie, R.T.; Wishart, G.N.; Flack, R.S.; et al. Preclinical characterization of the CDK4/6 inhibitor LY2835219: In-vivo cell cycle-dependent/independent anti-tumor activities alone/in combination with gemcitabine. Investig. New Drugs 2014, 32, 825-837. [CrossRef]

46. Ali, S.; Heathcote, D.A.; Kroll, S.H.B.; Jogalekar, A.S.; Scheiper, B.; Patel, H.; Brackow, J.; Siwicka, A.; Fuchter, M.J.; Periyasamy, M.; et al. The Development of a Selective Cyclin-Dependent Kinase Inhibitor That Shows Antitumor Activity. Cancer Res. 2009, 69, 6208-6215. [CrossRef]

47. Wang, S.; Fischer, P. Cyclin-dependent kinase 9: A key transcriptional regulator and potential drug target in oncology, virology and cardiology. Trends Pharmacol. Sci. 2008, 29, 302-313. [CrossRef]

48. Echalier, A.; Bettayeb, K.; Ferandin, Y.; Lozach, O.; Clément, M.; Valette, A.; Liger, F.; Marquet, B.; Morris, J.C.; Endicott, J.A.; et al. Meriolins (3-(Pyrimidin-4-yl)-7-azaindoles): Synthesis, Kinase Inhibitory Activity, Cellular Effects, and Structure of a CDK2/Cyclin A/Meriolin Complext. J. Med. Chem. 2008, 51, 737-751. [CrossRef] [PubMed]

49. Bettayeb, K.; Tirado, O.M.; Marionneau-Lambot, S.; Ferandin, Y.; Lozach, O.; Morris, J.C.; Mateo-Lozano, S.; Drueckes, P.; Schächtele, C.; Kubbutat, M.H.; et al. Meriolins, a New Class of Cell Death-Inducing Kinase Inhibitors with Enhanced Selectivity for Cyclin-Dependent Kinases. Cancer Res. 2007, 67, 8325-8334. [CrossRef] [PubMed]

50. Sonawane, Y.A.; Taylor, M.A.; Napoleon, J.V.; Rana, S.; Contreras, J.I.; Natarajan, A. Cyclin Dependent Kinase 9 Inhibitors for Cancer Therapy. J. Med. Chem. 2016, 59, 8667-8684. [CrossRef]

51. Parrino, B.; Attanzio, A.; Spanò, V.; Cascioferro, S.; Montalbano, A.; Barraja, P.; Tesoriere, L.; Diana, P.; Cirrincione, G.; Carbone, A. Synthesis, antitumor activity and CDK1 inhibiton of new thiazole nortopsentin analogues. Eur. J. Med. Chem. 2017, 138, 371-383. [CrossRef] [PubMed] 
52. Byth, K.F.; Thomas, A.; Hughes, G.; Forder, C.; McGregor, A.; Geh, C.; Oakes, S.; Green, C.; Walker, M.; Newcombe, N.; et al. AZD5438, a potent oral inhibitor of cyclin-dependent kinases 1,2, and 9, leads to pharmacodynamic changes and potent antitumor effects in human tumor xenografts. Mol. Cancer Ther. 2009, 8, 1856-1866. [CrossRef]

53. Siemeister, G.; Lücking, U.; Wengner, A.M.; Lienau, P.; Steinke, W.; Schatz, C.; Mumberg, D.; Ziegelbauer, K. BAY 1000394, a Novel Cyclin-Dependent Kinase Inhibitor, with Potent Antitumor Activity in Mono- and in Combination Treatment upon Oral Application. Mol. Cancer Ther. 2012, 11, 2265-2273. [CrossRef] [PubMed]

54. Chen, R.; Wierda, W.G.; Chubb, S.; Hawtin, R.E.; Fox, J.A.; Keating, M.J.; Gandhi, V.; Plunkett, W. Mechanism of action of SNS-032, a novel cyclin-dependent kinase inhibitor, in chronic lymphocytic leukemia. Blood 2009, 113, 4637-4645. [CrossRef] [PubMed]

55. Mousseau, G.; Mediouni, S.; Valente, S.T. Targeting HIV transcription: The quest for a functional cure. Curr. Top. Microbiol. Immunol. 2015, 389, 121-145. [CrossRef] [PubMed]

56. Walker, S.R.; Carter, E.J.; Huff, B.C.; Morris, J.C. Variolins and Related Alkaloids. Chem. Rev. 2009, 109, 3080-3098. [CrossRef]

57. Gompel, M.; Leost, M.; Joffe, E.B.D.K.; Puricelli, L.; Franco, L.H.; Palermo, J.; Meijer, L. Meridianins, a new family of protein kinase inhibitors isolated from the Ascidian Aplidium meridianum. Bioorganic Med. Chem. Lett. 2004, 14, 1703-1707. [CrossRef]

58. Carbone, A.; Pennati, M.; Parrino, B.; Lopergolo, A.; Barraja, P.; Montalbano, A.; Spanò, V.; Sbarra, S.; Doldi, V.; De Cesare, M.; et al. Novel 1H-Pyrrolo[2,3-b]pyridine Derivative Nortopsentin Analogues: Synthesis and Antitumor Activity in Peritoneal Mesothelioma Experimental Models. J. Med. Chem. 2013, 56, 7060-7072. [CrossRef]

59. Perry, N.B.; Ettouati, L.; Litaudon, M.; Blunt, J.W.; Munro, M.H.; Parkin, S.; Hope, H. Alkaloids from the antarctic sponge Kirkpatrickia varialosa. Tetrahedron 1994, 50, 3987-3992. [CrossRef]

60. Trimurtulu, G.; Faulkner, D.; Perry, N.B.; Ettouati, L.; Litaudon, M.; Blunt, J.W.; Munro, M.H.; Jameson, G.B. Alkaloids from the antarctic sponge Kirkpatrickia varialosa. Part 2: Variolin A and N(3')-methyl tetrahydrovariolin B. Tetrahedron 1994, 50, 3993-4000. [CrossRef]

61. Simone, M.; Erba, E.; Damia, G.; Vikhanskaya, F.; Di Francesco, A.M.; Riccardi, R.; Bailly, C.; Cuevas, C.; Sousa-Faro, J.M.F.; D'Incalci, M. Variolin B and its derivate deoxy-variolin B: New marine natural compounds with cyclin-dependent kinase inhibitor activity. Eur. J. Cancer 2005, 41, 2366-2377. [CrossRef]

62. Bharate, S.B.; Yadav, R.R.; Battula, S.; Vishwakarma, R.A. Meridianins: Marine-derived potent kinase inhibitors. Mini-Reviews Med. Chem. 2012, 12, 618-631. [CrossRef]

63. Li, B.; Chonghaile, T.N.; Fan, Y.; Madden, S.F.; Klinger, R.; O’Connor, A.E.; Walsh, L.; O’Hurley, G.; Udupi, G.M.; Joseph, J.; et al. Therapeutic Rationale to Target Highly Expressed CDK7 Conferring Poor Outcomes in Triple-Negative Breast Cancer. Cancer Res. 2017, 77, 3834-3845. [CrossRef] [PubMed]

64. Walsby, E.; Lazenby, M.; Pepper, C.; Burnett, A.K. The cyclin-dependent kinase inhibitor SNS-032 has single agent activity in AML cells and is highly synergistic with cytarabine. Leukemia 2011, 25, 411-419. [CrossRef]

65. Reck, M.; Horn, L.; Novello, S.; Barlesi, F.; Albert, I.; Juhász, E.; Kowalski, D.; Robinet, G.; Cadranel, J.; Bidoli, P.; et al. Phase II Study of Roniciclib in Combination with Cisplatin/Etoposide or Carboplatin/Etoposide as First-Line Therapy in Patients with Extensive-Disease Small Cell Lung Cancer. J. Thorac. Oncol. 2019, 14, 701-711. [CrossRef] [PubMed]

66. Boss, D.; Schwartz, G.; Middleton, M.; Amakye, D.; Swaisland, H.; Midgley, R.; Ranson, M.; Danson, S.; Calvert, H.; Plummer, R.; et al. Safety, tolerability, pharmacokinetics and pharmacodynamics of the oral cyclin-dependent kinase inhibitor AZD5438 when administered at intermittent and continuous dosing schedules in patients with advanced solid tumours. Ann. Oncol. 2010, 21, 884-894. [CrossRef]

67. Sundaram, J.R.; Poore, C.P.; Bin Sulaimee, N.H.; Pareek, T.; Asad, A.B.M.A.; Rajkumar, R.; Cheong, W.F.; Wenk, M.R.; Dawe, G.S.; Chuang, K.-H.; et al. Specific Inhibition of p25/Cdk5 Activity by the Cdk5 Inhibitory Peptide Reduces Neurodegeneration In Vivo. J. Neurosci. 2013, 33, 334-343. [CrossRef]

68. Deng, Y.; Shipps, G.W.; Zhao, L.; Siddiqui, M.A.; Popovici-Muller, J.; Curran, P.J.; Duca, J.S.; Hruza, A.W.; Fischmann, T.O.; Madison, V.S.; et al. Modulating the interaction between CDK2 and cyclin A with a quinoline-based inhibitor. Bioorganic Med. Chem. Lett. 2014, 24, 199-203. [CrossRef] [PubMed]

69. Wu, S.Y.; McNae, I.; Kontopidis, G.; McClue, S.J.; McInnes, C.; Stewart, K.J.; Wang, S.; Zheleva, D.I.; Marriage, H.; Lane, D.P.; et al. Discovery of a Novel Family of CDK Inhibitors with the Program LIDAEUS: Structural Basis for Ligand-Induced Disordering of the Activation Loop. Structure 2003, 11, 399-410. [CrossRef]

70. Martin, M.P.; Endicott, J.A.; Noble, M.E. Structure-based discovery of cyclin-dependent protein kinase inhibitors. Essays Biochem. 2017, 61, 439-452. [CrossRef] [PubMed]

71. Hari, S.B.; Merritt, E.A.; Maly, D.J. Sequence Determinants of a Specific Inactive Protein Kinase Conformation. Chem. Biol. 2013, 20, 806-815. [CrossRef] [PubMed]

72. Jura, N.; Zhang, X.; Endres, N.F.; Seeliger, M.A.; Schindler, T.; Kuriyan, J. Catalytic Control in the EGF Receptor and Its Connection to General Kinase Regulatory Mechanisms. Mol. Cell 2011, 42, 9-22. [CrossRef] [PubMed]

73. Jeffrey, L.; Robert, L.J.-L.J.A.A.C. Targeting Protein Multiple Conformations: A Structure-Based Strategy for Kinase Drug Design. Curr. Top. Med. Chem. 2007, 7, 1394-1407. [CrossRef]

74. Wohlbold, L.; Merrick, K.A.; De, S.; Amat, R.; Kim, J.H.; LaRochelle, S.; Allen, J.J.; Zhang, C.; Shokat, K.M.; Petrini, J.H.J.; et al. Chemical Genetics Reveals a Specific Requirement for Cdk2 Activity in the DNA Damage Response and Identifies Nbs1 as a Cdk2 Substrate in Human Cells. PLoS Genet. 2012, 8, e1002935. [CrossRef] 
75. Hasegawa, M.; Nishigaki, N.; Washio, Y.; Kano, K.; Harris, P.A.; Sato, H.; Mori, I.; West, R.I.; Shibahara, M.; Toyoda, H.; et al. Discovery of Novel Benzimidazoles as Potent Inhibitors of TIE-2 and VEGFR-2 Tyrosine Kinase Receptors. J. Med. Chem. 2007, 50, 4453-4470. [CrossRef]

76. Emrick, M.A.; Lee, T.; Starkey, P.J.; Mumby, M.C.; Resing, K.A.; Ahn, N.G. The gatekeeper residue controls autoactivation of ERK2 via a pathway of intramolecular connectivity. Proc. Natl. Acad. Sci. USA 2006, 103, 18101-18106. [CrossRef]

77. Azam, M.; A Seeliger, M.; Gray, N.S.; Kuriyan, J.; Daley, G.Q. Activation of tyrosine kinases by mutation of the gatekeeper threonine. Nat. Struct. Mol. Biol. 2008, 15, 1109-1118. [CrossRef] [PubMed]

78. Quintas-Cardama, A.; Tong, W.; Manshouri, T.; Vega, F.; A Lennon, P.; Cools, J.; Gilliland, D.G.; Lee, F.; Cortés, J.; Kantarjian, H.; et al. Activity of tyrosine kinase inhibitors against human NUP214-ABL1-positive T cell malignancies. Leukemia 2008, 22, 1117-1124. [CrossRef] [PubMed]

79. Vijayan, R.S.K.; He, P.; Modi, V.; Duong-Ly, K.C.; Ma, H.; Peterson, J.R.; Dunbrack, R.L.; Levy, R.M. Conformational Analysis of the DFG-Out Kinase Motif and Biochemical Profiling of Structurally Validated Type II Inhibitors. J. Med. Chem. 2015, 58, 466-479. [CrossRef]

80. Griffith, J.; Black, J.; Faerman, C.; Swenson, L.; Wynn, M.; Lu, F.; Lippke, J.; Saxena, K. The Structural Basis for Autoinhibition of FLT3 by the Juxtamembrane Domain. Mol. Cell 2004, 13, 169-178. [CrossRef]

81. Wang, Z.; Harkins, P.C.; Ulevitch, R.J.; Han, J.; Cobb, M.H.; Goldsmith, E.J. The structure of mitogen-activated protein kinase p38 at 2.1-Åresolution. Proc. Natl. Acad. Sci. USA 1997, 94, 2327-2332. [CrossRef] [PubMed]

82. Shan, Y.; Seeliger, M.A.; Eastwood, M.P.; Frank, F.; Xu, H.; Jensen, M.Ø.; Dror, R.O.; Kuriyan, J.; Shaw, D.E. A conserved protonation-dependent switch controls drug binding in the Abl kinase. Proc. Natl. Acad. Sci. USA 2009, 106, 139-144. [CrossRef] [PubMed]

83. Atwell, S.; Adams, J.M.; Badger, J.; Buchanan, M.D.; Feil, I.K.; Froning, K.J.; Gao, X.; Hendle, J.; Keegan, K.; Leon, B.C.; et al. A Novel Mode of Gleevec Binding Is Revealed by the Structure of Spleen Tyrosine Kinase. J. Biol. Chem. 2004, 279, 55827-55832. [CrossRef]

84. Liao, J.J.-L. Molecular Recognition of Protein Kinase Binding Pockets for Design of Potent and Selective Kinase Inhibitors. J. Med. Chem. 2007, 50, 409-424. [CrossRef] [PubMed]

85. Alexander, L.T.; Möbitz, H.; Drueckes, P.; Savitsky, P.; Fedorov, O.; Elkins, J.M.; Deane, C.M.; Cowan-Jacob, S.W.; Knapp, S. Type II Inhibitors Targeting CDK2. ACS Chem. Biol. 2015, 10, 2116-2125. [CrossRef] [PubMed]

86. Tan, L.; Gurbani, D.; Weisberg, E.L.; Hunter, J.C.; Li, L.; Jones, D.S.; Ficarro, S.B.; Mowafy, S.; Tam, C.-P.; Rao, S.; et al. Structureguided development of covalent TAK1 inhibitors. Bioorganic Med. Chem. 2017, 25, 838-846. [CrossRef]

87. Russo, A.A.; Jeffrey, P.D.; Patten, A.K.; Massagué, J.; Pavletich, N.P. Crystal structure of the p27Kip1 cyclin-dependent-kinase inibitor bound to the cyclin A-Cdk2 complex. Nature 1996, 382, 325-331. [CrossRef]

88. Jeffrey, P.D.; Tong, L.; Pavletich, N.P. Structural basis of inhibition of CDK-cyclin complexes by INK4 inhibitors. Genes Dev. 2000, 14, 3115-3125. [CrossRef] [PubMed]

89. McInnes, C.; Andrews, M.J.I.Z.; Daniella, I.; Lane, D.P.; Fischer, P.M. Peptidomimetic Design of CDK Inhibitors Targeting theRecruitment Site of the Cyclin Subunit. Curr. Med. Chem. Anti-Cancer Agents 2003, 3, 57-69.

90. Kontopidis, G.; Andrews, M.J.; McInnes, C.; Plater, A.; Innes, L.; Renachowski, S.; Cowan, A.; Fischer, P.M. Truncation and Optimisation of Peptide Inhibitors of Cyclin-Dependent Kinase 2-Cyclin A Through Structure-Guided Design. ChemMedChem 2009, 4, 1120-1128. [CrossRef] [PubMed]

91. Sánchez-Martínez, C.; Gelbert, L.M.; Lallena, M.J.; de Dios, A. Cyclin dependent kinase (CDK) inhibitors as anticancer drugs. Bioorganic Med. Chem. Lett. 2015, 25, 3420-3435. [CrossRef]

92. MM D37K. Available online: https://adisinsight.springer.com/drugs/800040966 (accessed on 20 January 2021).

93. Schneider, E.V.; Böttcher, J.; Blaesse, M.; Neumann, L.; Huber, R.; Maskos, K. The Structure of CDK8/CycC Implicates Specificity in the CDK/Cyclin Family and Reveals Interaction with a Deep Pocket Binder. J. Mol. Biol. 2011, 412, 251-266. [CrossRef]

94. Bergeron, P.; Koehler, M.F.T.; Blackwood, E.M.; Bowman, K.; Clark, K.; Firestein, R.; Kiefer, J.R.; Maskos, K.; McCleland, M.L.; Orren, L.; et al. Design and Development of a Series of Potent and Selective Type II Inhibitors of CDK8. ACS Med. Chem. Lett. 2016, 7, 595-600. [CrossRef] [PubMed]

95. Wilhelm, S.M.; Adnane, L.; Newell, P.; Villanueva, A.; Llovet, J.M.; Lynch, M. Preclinical overview of sorafenib, a multikinase inhibitor that targets both Raf and VEGF and PDGF receptor tyrosine kinase signaling. Mol. Cancer Ther. 2008, 7, 3129-3140. [CrossRef]

96. Wilhelm, S.M.; Carter, C.; Tang, L.; Wilkie, D.; McNabola, A.; Rong, H.; Chen, C.; Zhang, X.; Vincent, P.; McHugh, M.; et al. BAY 43-9006 Exhibits Broad Spectrum Oral Antitumor Activity and Targets the RAF/MEK/ERK Pathway and Receptor Tyrosine Kinases Involved in Tumor Progression and Angiogenesis. Cancer Res. 2004, 64, 7099-7109. [CrossRef] [PubMed]

97. Molina, J.R.; Adjei, A.A. The Ras/Raf/MAPK Pathway. J. Thorac. Oncol. 2006, 1, 7-9. [CrossRef]

98. Dale, T.C.; Clarke, P.A.; Esdar, C.; Waalboer, D.; Adeniji-Popoola, O.; Ortiz-Ruiz, M.-J.; Mallinger, A.; Samant, R.S.; Czodrowski, P.; Musil, D.; et al. A selective chemical probe for exploring the role of CDK8 and CDK19 in human disease. Nat. Chem. Biol. 2015, 11, 973-980. [CrossRef]

99. Nagaria, T.S.; Williams, J.L.; LeDuc, C.; A Squire, J.; A Greer, P.; Sangrar, W. Flavopiridol Synergizes with Sorafenib to Induce Cytotoxicity and Potentiate Antitumorigenic Activity in EGFR/HER-2 and Mutant RAS/RAF Breast Cancer Model Systems. Neoplasia 2013, 15, 939-IN27. [CrossRef] 
100. Mancini, M.; Yarden, Y. Mutational and network level mechanisms underlying resistance to anti-cancer kinase inhibitors. Semin. Cell Dev. Biol. 2016, 50, 164-176. [CrossRef]

101. Adrián, F.J.; Ding, Q.; Sim, T.; Velentza, A.V.; Sloan, C.; Liu, Y.; Zhang, G.; Hur, W.; Ding, S.; Manley, P.W.; et al. Allosteric inhibitors of Bcr-abl-dependent cell proliferation. Nat. Chem. Biol. 2006, 2, 95-102. [CrossRef]

102. Sebolt-Leopold, J.S.; Dudley, D.T.; Herrera, R.; Van Becelaere, K.; Wiland, A.; Gowan, R.C.; Tecle, H.; Barrett, S.D.; Bridges, A.; Przybranowski, S.; et al. Blockade of the MAP kinase pathway suppresses growth of colon tumors in vivo. Nat. Med. 1999, 5, 810-816. [CrossRef]

103. Gavrin, L.K.; Saiah, E. Approaches to discover non-ATP site kinase inhibitors. MedChemComm 2013, 4, 41-51. [CrossRef]

104. Yueh, C.; Rettenmaier, J.; Xia, B.; Hall, D.R.; Alekseenko, A.; Porter, K.A.; Barkovich, K.; Keseru, G.M.; Whitty, A.; Wells, J.A.; et al. Kinase Atlas: Druggability Analysis of Potential Allosteric Sites in Kinases. J. Med. Chem. 2019, 62, 6512-6524. [CrossRef] [PubMed]

105. Kozakov, D.; Grove, L.E.; Hall, D.R.; Bohnuud, T.; E Mottarella, S.; Luo, L.; Xia, B.; Beglov, D.; Vajda, S. The FTMap family of web servers for determining and characterizing ligand-binding hot spots of proteins. Nat. Protoc. 2015, 10, 733-755. [CrossRef]

106. Betzi, S.; Alam, R.; Martin, M.; Lubbers, D.J.; Han, H.; Jakkaraj, S.R.; Georg, G.I.; Schönbrunn, E. Discovery of a Potential Allosteric Ligand Binding Site in CDK2. ACS Chem. Biol. 2011, 6, 492-501. [CrossRef] [PubMed]

107. Parang, K.; Till, J.H.; Ablooglu, A.J.; A Kohanski, R.; Hubbard, S.; A Cole, P. Mechanism-based design of a protein kinase inhibitor. Nat. Genet. 2001, 8, 37-41. [CrossRef]

108. Poot, A.J.; Van Ameijde, J.; Slijper, M.; Berg, A.V.D.; Hilhorst, R.; Ruijtenbeek, R.; Rijkers, D.T.S.; Liskamp, R.M.J. Development of Selective Bisubstrate-Based Inhibitors Against Protein Kinase C (PKC) Isozymes By Using Dynamic Peptide Microarrays. ChemBioChem 2009, 10, 2042-2051. [CrossRef] [PubMed]

109. Gower, C.M.; Chang, M.E.K.; Maly, D.J. Bivalent inhibitors of protein kinases. Crit. Rev. Biochem. Mol. Biol. 2013, 49, 102-115. [CrossRef]

110. Hill, Z.B.; Perera, B.G.K.; Maly, D.J. A Chemical Genetic Method for Generating Bivalent Inhibitors of Protein Kinases. J. Am. Chem. Soc. 2009, 131, 6686-6688. [CrossRef] [PubMed]

111. Kedika, S.R.; Udugamasooriya, D.G. Converting a weaker ATP-binding site inhibitor into a potent hetero-bivalent ligand by tethering to a unique peptide sequence derived from the same kinase. Org. Biomol. Chem. 2018, 16, 6443-6449. [CrossRef]

112. Wong, M.L.; Murphy, J.; Harrington, E.; Gower, C.M.; Jain, R.K.; Schirle, M.; Thomas, J.R. Examining the influence of specificity ligands and ATP-competitive ligands on the overall effectiveness of bivalent kinase inhibitors. Proteome Sci. 2016, 15, 17. [CrossRef] [PubMed]

113. Vane, J.; Botting, R. The mechanism of action of aspirin. Thromb. Res. 2003, 110, 255-258. [CrossRef]

114. McCrae, J.C.; Morrison, E.E.; MacIntyre, I.M.; Dear, J.W.; Webb, D.J. Long-term adverse effects of paracetamol—A review. Br. J. Clin. Pharmacol. 2018, 84, 2218-2230. [CrossRef] [PubMed]

115. Gehringer, M.; Laufer, S.A. Emerging and Re-Emerging Warheads for Targeted Covalent Inhibitors: Applications in Medicinal Chemistry and Chemical Biology. J. Med. Chem. 2019, 62, 5673-5724. [CrossRef] [PubMed]

116. Kwiatkowski, N.P.; Zhang, T.; Rahl, P.B.; Abraham, B.J.; Reddy, J.; Ficarro, S.B.; Dastur, A.; Amzallag, A.; Ramaswamy, S.; Tesar, B.; et al. Targeting transcription regulation in cancer with a covalent CDK7 inhibitor. Nat. Cell Biol. 2014, 511, 616-620. [CrossRef] [PubMed]

117. Hu, S.; Marineau, J.J.; Rajagopal, N.; Hamman, K.B.; Choi, Y.J.; Schmidt, D.R.; Ke, N.; Johannessen, L.; Bradley, M.J.; Orlando, D.A.; et al. Discovery and Characterization of SY-1365, a Selective, Covalent Inhibitor of CDK7. Cancer Res. 2019, 79, 3479-3491. [CrossRef] [PubMed]

118. Zhang, T.; Kwiatkowski, N.; Olson, C.M.; E Dixon-Clarke, S.; Abraham, B.J.; Greifenberg, A.K.; Ficarro, S.B.; Elkins, J.M.; Liang, Y.; Hannett, N.M.; et al. Covalent targeting of remote cysteine residues to develop CDK12 and CDK13 inhibitors. Nat. Chem. Biol. 2016, 12, 876-884. [CrossRef] [PubMed]

119. Gao, Y.; Zhang, T.; Terai, H.; Ficarro, S.B.; Kwiatkowski, N.; Hao, M.-F.; Sharma, B.; Christensen, C.L.; Chipumuro, E.; Wong, K.-K.; et al. Overcoming Resistance to the THZ Series of Covalent Transcriptional CDK Inhibitors. Cell Chem. Biol. 2018, 25, 135-142.e5. [CrossRef] [PubMed]

120. Burger, J.A.; Barr, P.M.; Robak, T.; Owen, C.; Ghia, P.; Tedeschi, A.; Bairey, O.; Hillmen, P.; Coutre, S.E.; Devereux, S.; et al. Long-term efficacy and safety of first-line ibrutinib treatment for patients with CLL/SLL: 5 years of follow-up from the phase 3 RESONATE-2 study. Leukemia 2020, 34, 787-798. [CrossRef]

121. Park, K.; Tan, E.-H.; O’Byrne, K.; Zhang, L.; Boyer, M.; Mok, T.; Hirsh, V.; Yang, J.C.-H.; Lee, K.H.; Lu, S.; et al. Afatinib versus gefitinib as first-line treatment of patients with EGFR mutation-positive non-small-cell lung cancer (LUX-Lung 7): A phase 2B, open-label, randomised controlled trial. Lancet Oncol. 2016, 17, 577-589. [CrossRef]

122. Liu, R.; Yue, Z.; Tsai, C.-C.; Shen, J. Assessing Lysine and Cysteine Reactivities for Designing Targeted Covalent Kinase Inhibitors. J. Am. Chem. Soc. 2019, 141, 6553-6560. [CrossRef] [PubMed]

123. Coll-Martínez, B.; Delgado, A.; Crosas, B. The Potential of Proteolytic Chimeras as Pharmacological Tools and Therapeutic Agents. Molecules 2020, 25, 5956. [CrossRef] [PubMed]

124. Osborne, C.K.; Wakeling, A.; I Nicholson, R. Fulvestrant: An oestrogen receptor antagonist with a novel mechanism of action. Br. J. Cancer 2004, 90, S2-S6. [CrossRef] [PubMed] 
125. Chopra, R.; Sadok, A.; Collins, I. A critical evaluation of the approaches to targeted protein degradation for drug discovery. Drug Discov. Today Technol. 2019, 31, 5-13. [CrossRef]

126. Ito, T.; Ando, H.; Suzuki, T.; Ogura, T.; Hotta, K.; Imamura, Y.; Yamaguchi, Y.; Handa, H. Identification of a Primary Target of Thalidomide Teratogenicity. Science 2010, 327, 1345-1350. [CrossRef] [PubMed]

127. Fouad, S.; Wells, O.S.; Hill, M.A.; D'Angiolella, V. Cullin Ring Ubiquitin Ligases (CRLs) in Cancer: Responses to Ionizing Radiation (IR) Treatment. Front. Physiol. 2019, 10, 1144. [CrossRef]

128. Bettayeb, K.; Oumata, N.; Echalier, A.; Ferandin, Y.; A Endicott, J.; Galons, H.; Meijer, L. CR8, a potent and selective, roscovitinederived inhibitor of cyclin-dependent kinases. Oncogene 2008, 27, 5797-5807. [CrossRef]

129. Słabicki, M.; Kozicka, Z.; Petzold, G.; Li, Y.-D.; Manojkumar, M.; Bunker, R.D.; Donovan, K.A.; Sievers, Q.L.; Koeppel, J.; Suchyta, D.; et al. The CDK inhibitor CR8 acts as a molecular glue degrader that depletes cyclin K. Nature 2020, 585, 293-297. [CrossRef] [PubMed]

130. Naito, M.; Ohoka, N.; Shibata, N.; Tsukumo, Y. Targeted Protein Degradation by Chimeric Small Molecules, PROTACs and SNIPERs. Front. Chem. 2019, 7, 849. [CrossRef] [PubMed]

131. Zhao, B.; Burgess, K. PROTACs suppression of CDK4/6, crucial kinases for cell cycle regulation in cancer. Chem. Commun. 2019, 55, 2704-2707. [CrossRef]

132. Jiang, B.; Wang, E.S.; Donovan, K.A.; Liang, Y.; Fischer, E.S.; Zhang, T.; Gray, N.S. Development of Dual and Selective Degraders of Cyclin-Dependent Kinases 4 and 6. Angew. Chem. Int. Ed. 2019, 58, 6321-6326. [CrossRef]

133. Brand, M.; Jiang, B.; Bauer, S.; Donovan, K.A.; Liang, Y.; Wang, E.S.; Nowak, R.P.; Yuan, J.C.; Zhang, T.; Kwiatkowski, N.; et al. Homolog-Selective Degradation as a Strategy to Probe the Function of CDK6 in AML. Cell Chem. Biol. 2019, 26, 300-306.e9. [CrossRef]

134. Su, S.; Yang, Z.; Gao, H.; Yang, H.; Zhu, S.; An, Z.; Wang, J.; Li, Q.; Chandarlapaty, S.; Deng, H.; et al. Potent and Preferential Degradation of CDK6 via Proteolysis Targeting Chimera Degraders. J. Med. Chem. 2019, 62, 7575-7582. [CrossRef] [PubMed]

135. Yang, C.; Li, Z.; Bhatt, T.; Dickler, M.; Giri, D.; Scaltriti, M.; Baselga, J.; Rosen, N.; Chandarlapaty, S. Acquired CDK6 amplification promotes breast cancer resistance to CDK4/6 inhibitors and loss of ER signaling and dependence. Oncogene 2017, 36, 2255-2264. [CrossRef]

136. Rzymski, T.; Mikula, M.; Wiklik, K.; Brzózka, K. CDK8 kinase-An emerging target in targeted cancer therapy. Biochim. Biophys. Acta (BBA) Proteins Proteom. 2015, 1854, 1617-1629. [CrossRef]

137. Hatcher, J.M.; Wang, E.S.; Johannessen, L.; Kwiatkowski, N.; Sim, T.; Gray, N.S. Development of Highly Potent and Selective Steroidal Inhibitors and Degraders of CDK8. ACS Med. Chem. Lett. 2018, 9, 540-545. [CrossRef] [PubMed]

138. Bagella, L.; MacLachlan, T.K.; Buono, R.J.; Pisano, M.M.; Giordano, A.; De Luca, A. Cloning of murine CDK9/PITALRE and its tissue-specific expression in development. J. Cell. Physiol. 1998, 177, 206-213. [CrossRef]

139. Vladimir, K.; Stjepan, U. Cyclin-Dependent Kinase Inhibitors as Anticancer Drugs. Curr. Drug Targets 2010, 11, 291-302. [CrossRef]

140. Petzold, G.; Fischer, E.S.; Thomä, G.P.E.S.F.N.H. Structural basis of lenalidomide-induced CK1 $\alpha$ degradation by the CRL4CRBN ubiquitin ligase. Nat. Cell Biol. 2016, 532, 127-130. [CrossRef] [PubMed]

141. Robb, C.M.; Contreras, J.I.; Kour, S.; Taylor, M.A.; Abid, M.; Sonawane, Y.A.; Zahid, M.; Murry, D.J.; Natarajan, A.; Rana, S. Chemically induced degradation of CDK9 by a proteolysis targeting chimera (PROTAC). Chem. Commun. 2017, 53, 7577-7580. [CrossRef] [PubMed]

142. Olson, C.M.; Jiang, B.; Erb, M.A.; Liang, Y.; Doctor, Z.M.; Zhang, Z.; Zhang, T.; Kwiatkowski, N.; Boukhali, M.; Green, J.L.; et al. Pharmacological perturbation of CDK9 using selective CDK9 inhibition or degradation. Nat. Chem. Biol. 2018, 14, 163-170. [CrossRef] [PubMed]

143. Bian, J.; Ren, J.; Li, Y.; Wang, J.; Xu, X.; Feng, Y.; Tang, H.; Wang, Y.; Li, Z. Discovery of Wogonin-based PROTACs against CDK9 and capable of achieving antitumor activity. Bioorganic Chem. 2018, 81, 373-381. [CrossRef] 